\title{
Gardens of Empire: Imperial Practices and the Construction of a New Imperial Space
}

\section{Serguey N. Yakushenkov (a) \& Alexander Yu. Meshcheryakov (b)}

(a) Astrakhan State University. Astrakhan, Russia. Email: shuilong[at]mail.ru

(b) National Research University "Higher School of Economics University". St. Petersburg, Russia. Email: daomesheryakov[at]gmail.com

\begin{abstract}
The Empire, as one of the political forms of state systems, existed at all times and on all continents. Its main feature has been the unification of numerous ethnic groups with different cultural, political and economic characteristics under a Center. Usually this unification led to the establishment of domination over the subjugated peoples with the help of imperial practices. One of these is the botanical garden.

The imperial garden idea expressed many concepts of Empire: ideological, political, cultural, educational, etc. This institution was primarily intended to underline the Empire greatness through metaphors of center, paradise, prosperity, unity of different parties, etc. This was evident in the Modern history Empires, which arose because of the West's special interest in plant resources or their accompanying commodities: spices, sugar, silk, cotton, and others. The imperial garden in this time was designed to serve the Metropolis interests and at the same time for the colony development, which was carried out in accordance with the Center interests.

The formation of this institution in Russia took place simultaneously in the Center and on the Frontier. The Astrakhan case shows well how this institution was formed in the region in the 18th century according to national trends. While some regions made progress during this period, the Center exhibited the opposite trend. After the breakthrough in the Petrine era, the development of this institution was not in line with the Empire objectives. In the 19th century, a tendency to realize the importance of this institution appeared again.
\end{abstract}

Keywords

Empire; Imperial Practices; Peter the Great; Apothecary Garden; Botanical Garden; Astrakhan; Frontier Cases

This work is licensed under a Creative Commons "Attribution" 4.0 International License 


\section{Сады империи: имперские практики и конструирование нового имперского пространства}

\section{Якушенков Сергей Николаевич (a) \& Мещеряков Александр Юрьевич (b)}

(a) Астраханский государственный университет. Астрахань, Россия. Email: shuilong[at]mail.ru

(b) Национальный исследовательский университет «Высшая школа экономики». Санкт-Петербург, Россия. Email: daomesheryakov[at]gmail.com

\section{Аннотация}

Империя, как одна из политических форм государственного устройства, существовала во все времена и на всех континентах. Ее основной чертой было объединение многочисленных этносов с различным культурными, политическими и экономическими характеристиками под эгидой центра, выражающего интересы определенной группы населения. Это объединение, как правило, осуществлялось путем принуждения и приводило к установления господства над покоренными народами в интересах метрополии. Но это доминирование на присоединенных территориях реализовывалось с помощью имперских практик, которые не всегда были насильственными. Одной из них является ботанический сад.

Идея имперского сада как нельзя лучше выражает многие концепции империи: идеологические, политические, культурные, просветительские и т.д. Данный институт призван указать на величие империи через метафоры центра, рая, процветания, единения разных сторон и стран мира. Особо ярко это проявилось в империях Нового времени, возникавших из-за особого интереса Запада ко многим растительным ресурсам или сопутствующим им товарам: специям, сахару, шелку, хлопку и другим. Имперский сад в Новое время призван обслуживать интересы метрополии и одновременно развитие колонии, однако, это развитие осуществляется в соответствии с интересами Центра.

Становление этого института в России происходило одновременно и в Центре, и на фронтирной территории. Астраханский кейс хорошо показывает, как этот институт формировался в регионе в XVIII в. в соответствии с общенациональными тенденциями. Если в ряде регионов в этот период наметился прогресс, то в силу ряда причин в Центре проявилась обратная тенденция. После прорыва в Петровскую эпоху, развитие этого института не соответствовало задачам империи. В XIX в. вновь наблюдается интерес к этому вопросу.

\section{Ключевые слова}

империя; имперские практики; Петр I; аптекарский огород; ботанический сад; Астрахань; фронтирные кейсы

Это произведение доступно по лицензии Creative Commons “Attribution” («Атрибуция») 4.0 Всемирная 


\section{Введение}

Our England is a garden that is full of stately

views,

Of borders, beds and shrubberies and lawns and avenues,

With statues on the terraces and peacocks strutting

by

But the Glory of the Garden lies in more than meets

the eye $e^{1}$ (Kipling, 1897, p. 183) "The Glory of the Garden"

Один из авторов этой статьи на одном из первых симпозиумов индеанистов $^{2}$, проводимых в СССР в конце 70-х гг., был свидетелем интересного и во многом сенсационного выступления видного советского археолога и специалиста по городам-государствам майя В. Гуляева. В своей речи он неожиданно поднял очень важную тему отсутствия в советской историографии четкой дефиниций понятия империя. Его выступление сводилось к описанию некой курьезной ситуации, заключающейся в том, что все его попытки выяснить, а что такое империя, были обречены на провал. Он так и не разобрался, а что же в советской исторической науке понимают под этим термином. В качестве иллюстрации он привел словарные статьи из «Советской исторической энциклопедии». Словарная статья гласила:

ИМПЕРИя - 1) Наименование монархического государства, главой которого является император. 2) Империей иногда называют организацию колониального господства отдельных буржуазных государств. В этом смысле говорят о Британской империи, о Французской колониальной империи (несмотря на республиканский характер государственного строя Франции) и т.д. (Советская Историческая Энииклопедия, 1964, с. 823).

Поиск дальнейшей информации также обескуражил В. Гуляева: словарная статья на термин «император» ни в коей мере не проясняла понятие

1 Наша Англия - это сад, полный величественных видов,

Бордюров, клумб и кустарников, газонов и аллей,

Со статуями на террасах и павлинами, расхаживающими вокруг них

Но величие сада - это нечто большее, чем кажется на первый взгляд. (Перевод автор.)

2 Этот термин мы используем здесь не в значении сторонников индеанизма - политического движения, существующего в ряде стран Латинской Америки, а в отношении специалистов - этнологов, антропологов, археологов и историков, занимающихся изучением истории и культуры индейцев Америки. 
«империи», так как в упрощенном виде звучала приблизительно так: император - правитель, стоящий во главе империи:

ИМПЕРАТОР (лат. imperator, от impero - повелеваю) - титул некоторых монархов, обозначающий более высокий ранг по сравнению с королем, царем. Первоначально - почетный воинский титул в республиканском Риме, которым солдаты награждали полководца после крупной победы. Впервые титулом И. был награжден Л. Эмилий Павел (189 до н. э.), Помпей награждался им неоднократно. Цезарь стал пользоваться этим, титулом как постоянным, затем он перешел к Августу и его преемникам, приобретя явно монархический оттенок... (Там же, с. 806).

Но вряд ли эта ситуация улучшилась для тех, кто решить четко уяснить, а что же такое все-таки илперия. Во Введении к очень интересной монографии «Изобретение империи: языки и практики» авторы замечают:

$<$ Б>ольшинству обитателей империи не приходится размышлять о специфике окружающего их общества как империи: достаточно знать, что во главе страны стоит император и страна их официально зовется империей. С другой стороны, чтобы осознать эту «невидимость» и несамоочевидность империи как исследовательскую проблему, современные историки должны отдавать себе отчет в том, что имеют дело не с реальной «вещью», а с контекстуально обусловленным конструктом. Где находится империя, когда ее никто не видит? Что толку в «объективной» реконструкции структурных отношений господства и подчинения или политики территориальной экспансии, если те же самые структуры и политику можно найти в любой другой форме политического устройства во все эпохи? (Герасимов et al., 2011, cc. 7-8)

Повторяем, что монография очень интересная, и многие статьи, представленные в ней, действительно, заставляют задуматься об имперских практиках. Однако, так ли уж составители вправе говорить историкам (современные историки должны отдавать себе отчет), что и как они должны понимать? Назвать контекстуально обусловленныл конструктом в гуманитарных дисциплинах мы можем самые различные явления, и империю в том числе. Но от этого данный конструкт не перестанет быть интересен для исследователя. И даже напротив, значимость его как объекта многократно возрастет. Ведь актуализируется важность понимания отличительных граней этого конструкта, уяснения чем он отличен от других подобных политических образований. И, возможно, какому-то обывателю и достаточно знать, что он (она) живет в империи, а во главе их «контекстуально обусловленного конструкта» находится другой «конструкт», называющий себя и называемый другими императором. А вдруг обыватель захочет узнать, выучить эти самые «языки и практики изобретения империи»? Где тот вокабулярий, который он мог бы использовать, где эти законы грамматики и стилистики, на которые намекают составители монографии? 
Journal of Frontier Studies. 2022. No 1 | ISSN: 2500-0225

Imperial Practices | https://doi.org/10.46539/jfs.v7i1.373

К сожалению, мы все очень хорошо знали, что такое империализм, и ничего не знали о том, что такое империя. Но знаем ли мы сейчас? Где тот вокабулярий, который студент или начинающий ученый мог бы использовать для выяснения этого загадочного понятия?

Британский историк Э. Джонсон в предисловии к своей «Британской империи: очень краткое введение» сразу же поясняет:

Иногда книги о Британской империи ставят больше вопросов, чем предлагают ответов. Они подчеркивают сложность предмета и совершают экскурс в его историографические залежи, а не предлагают твердые ориентиры, чтобы читатели-новички могли ухватиться за них при восхождении по многоветвистому древу знаний о Британской империи. Такой осторожный подход отражает масштабность предмета, который в самом широком смысле представляет собой историю четверти мира на протяжении нескольких веков, и состоит из разнообразных и порой противоречивых историй, которые она породила. Но если перестраховаться из-за сложности и неоднородности предмета, читатель может почувствовать себя потерявшим ориентиры (Jackson, 2013).

Правда, надо отдать должное Э. Джексону. Он попытался обозначить ряд ключевых моментов, которые, как он считает, имеют отношение к Британской империи. Среди них он называет особую экономику, культурные универсалии, специфичную систему знаний, расовые конструкции, особое государственное устройство и военную систему, и ряд других факторов.

Но вряд ли эти признаки могут помочь начинающему историку, и здесь мы вынуждены согласиться с редакторами коллективной монографии «Изобретение империи: языки и практики» о том, что многие эти признаки могут быть найдены и «в любой другой форме политического устройства».

Американский историк Альфред Рибер, выступая в 2003 г. на международной конференции «История империй: сравнительный подход в преподавании и исследованиях», суммировал следующее:

Империи остаются все еще недостаточно исследованной областью знания в сопоставлении с их историческим и концептуальным соперником - национальным государством. Существует множество заслуживающих внимания теорий национализма и национального строительства, и в то же время - сравнительно мало теорий, объясняющих историю строительства и упадка империй и империализма (Рибер, 2004, с. 33).

Прошло почти 20 лет, но ситуация мало изменилась, так как историки старательно избегают вопросов общетеоретического характера, предпочитая разбирать исторические аспекты конкретных империй. И в этом плане коллективная монография «Изобретение империи» действительно касается ряда очень интересных имперских практик. Но вряд ли она может заполнить существующие лакуны в этом вопросе 1 . Сложность данной проблемы проистекает

1 Мы не можем обойти вниманием очень интересную коллективную монографию Empire Speaks Out (Империя высказывается), вышедшую в 2009 г. (Gerasimov et al., 2009). Здесь же читатель найдет небольшой список работ, посвященных исследованиям империй и имперских историй. 
из того, что длительное время этот термин был общепринятым, но как только его попытались рассмотреть повнимательнее, оказалось все не так просто:

Слово «империя» само по себе является неоднозначным, его значение и контексты, в которых оно могло быть использовано, постоянно менялись, пока в начале XVIII века оно не приобрело свое современное значение. Но его семантика все еще остается запутанной...(Pagden, 1998, p. 12).

Ситуация с «империей» сложна не в том плане, что постоянно трансформировалось значение этого термина. На протяжении длительного периода $\mathrm{XX}$ в. менялись подходы к изучению этого явления. Как только колониальные народы порвали со своим колониальным прошлым, они получили возможность говорить сами за себя, и для западных ученых вдруг стало ясно, что представления Других об империи могут кардинальным образом отличаться от их (Stoler, 2009, p. 34).

Опираясь на определение империи, данное Майклом У. Дойлем ${ }^{1}$ и Джоном А. Армстронгом², Рональд Г. Сани подытоживает:

Империя как особая форма господства или контроля между двумя единицами, находящимися в иерархических, неравноправных отношениях, точнее, составное государство, в котором метрополия доминирует над периферией в ущерб периферии (Suny \& Martin, 2001, p. 25).

Легко заметить, что в своих определениях большинство ученых обращают на моменты соподчинения, доминирования и гегемонии:

«Империя» как категория, которая формируется в современной исследовательской литературе, обозначает темы гегемонии, доминирования, взаимосвязанности и разнообразия, в то время как ее референтная значимость является множественной и противоречивой (Ilya Gerasimov et al., 2009, p. 5).

Но те же историки утверждали, что бессмысленно апеллировать к «структурным отношениям господства и подчинения или политике территориальной экспансии» (Герасимов et al., 2011, сc. 7-8). Конечно, не стоит, но и сбрасывать со счетов не надо. Не следует забывать, что «империя» - это динамичное явление, меняющееся во времени и пространстве. И в отдельные эпохи даже одни и те же империи представляли разные явления. Вполне понятно, что древние империи в значительной мере отличались от империй Нового времени. Однако, игнорировать общие моменты имперской типологии крайне неверно. Кимитака Мацузато считает, что современное состояние имперской

1 «Империя... представляет собой систему взаимодействия двух политических образований, одно из которых, доминирующий полюс метрополии, осуществляет политический контроль над внутренней и внешней политикой (действенный суверенитет) другого - подчиненной периферии. Для понимания этого взаимодействия необходимо объяснить как слабость периферии, так и силу, и мотивы метрополии» (Doyle, 1986, p. 12); «Империя - это отношения, формальные или неформальные, в которых одно государство контролирует эффективный политический суверенитет другого политического сообщества. Это может быть достигнуто силой, политическим сотрудничеством, экономической, социальной или культурной зависимостью» (Там же, р. 45).

2 «Империя - это не просто крупное государство, а государство, вобравшее в себя более мелкие государства» (Armstrong, 1982, p. 131). 
теории (имперологии) позволяет проводить аналогии между империями, возникшими после XVI в. и более ранними (Matsuzato, 2010, p. 14).

Но как бы не были разведены империи по времени или географии друг от друга, как нам кажется, найдется множество черт, которые объединяют их в то, что мы и определяем с помощью этого термина.

Среди множества этих черт, мы бы назвали две основных черты, которые, по нашему мнению, всегда были основополагающими для этого типа государственных образований или политий: организация пространства и идеология (или мифология). При этом в конструирование пространства будет включаться и множество других принципов (вертикальных и горизонтальных). К вертикальным мы относим вопросы гегемонии, доминирования, распределение власти и ресурсов, военные и др.. К горизонтальным - политические и государственные структуры, коммуникационные и ряд других.

Имперские мифологии или идеологии также состоят из нескольких подпринципов, сочетающих в себе секулярные и сакральные аспекты. К секулярным относятся вопросы общей имперской идеологии или миссии, а также языковая политика, мораль, культура, право, образование, медицина и т.д.. К сакральным относятся вопросы религии, исторической памяти, культ императора, культ центра и центральной власти, социальной космологии и т.д..

Часть этих аспектов могут быть классифицированы и в рамках пространственных, и идеологических характеристик. И в этом проявился еще один важнейший феномен имперского проекта - его универсализм. Каждый аспект реализуется в рамках нескольких базовых принципов. В результате идеология всегда вещественна - она находит реализацию в конкретных пространственных проектах, а в свою очередь пространство четко детерминировано идеологией.

Практически все эти черты можно найти во всех империях, и повсюду они будут реализованы очень схожим образом. Детали генерального плана могут разниться, но в целом, схожих моментов огромное число. В результате получается устойчивая система, ну или система стремится к устойчивости, достигая ее в разной степени.

Типичным примером подобной унифицированной системы может служить государство инков - Тауантинсуйу, ${ }^{1}$ представлявшее собой идеальный пример устройства ранних империй. Правда, гегемония инков состояла не из доминирования какого-то государства над другими, а доминирования одной этнической группы над другими политиями. Во главе государства стоял Великий Инка (Сапа инка), имевший сакральную природу. Система инкского

1 Учитывая то, что чаще всего анализ империй проводят на европейских примерах, ну или привлекая примеры из Персии (Daryaee, 2013; Newman, 2021; Waters, 2014), Индии (Balabanlilar, 2012; Moosvi, 1987;

Richards, 1993; Streusand, 1989) и т.д., мы решили выбрать для нашего анализа пример из Южной Америки, показав, что в основных параметрах имперская модель у инков будет во многом совпадать с общепринятыми представлениями об империи. Мы предлагаем читателям самим сравнить представленный по инкам материал с примерами из Старого Света. 
государства являла собой уникальное сочетание горизонтальных и вертикальных структур (Rostworowski de Diez Canseco, 2000; Zuidema, 1964, 1990) ${ }^{1}$. Инкам удалось создать огромную империю, протянувшуюся от южных районов Колумбии до северных районов Чили. А в широтном направлении от тропических лесов Амазонки до побережья Тихого океана. Империя объединяла сотни различных племен и народов, ряд которых находился на стадии формирования ранней государственности, другие (как некоторые амазонские племена) жили в раннеродовом строе.

В империи использовался один официальный язык - кечуа (руна-сими) ${ }^{2}$, который не был языком инков. Аккультурация совершалась с помощью такого института как митла - насильственного переселения. Колонисты (кеч. митимаес, митмак-куна) из центральных районов империи переселялись во вновь завоеванные. А часть жителей оттуда перемещались на освободившиеся земли в центральных районах. В результате образовывалась сложная ситуация, в которой «ненадежные» этнические группы оказывались зажатыми между индейцами кечуа, составлявшими основную этническую группу государства инков. Социализация происходила и с помощью построения единой мифологии и универсальной религиозной системы, в которую были вписаны и региональные культы различных народов империи. Культовые центры империи также располагались в различных уголках государства, создавая особую структуру. При этом часть региональных культов имели общегосударственное значение, как, например, сакральные центры на оз. Титикака (Dearborn et al., 1998), которые в состав государства инков достаточно поздно. С другой стороны, часть подобных центров являлись местами паломничества еще в доинкский период, а инки лишь вписали их в свою мифологию.

Административная система также была унифицирована и едина на всем пространстве империи. И вместе с тем она не могла не учитывать и местные культы, так как во многом опиралась на культ предков, связанных с местными святилищами. В результате в географическом плане государство инков

1 Следует пояснить, что Т. Зюйдема никогда не употреблял термина «империя» по отношению к инкам. И вместе с тем, система инкского государства, представленная в его исследования, как нам кажется, в значительной мере напоминает имперские практики. Мария Ростворовски де Диес Кансеко также не использует термин «империя» и даже специально оговаривает это, заявляя, что иначе это бы приводило к «множеству коннотаций со Старым Светом» (Rostworowski de Diez Canseco, 1999, p. Х). Она пытается подчеркнуть уникальность государства инков, непохожесть его на государственные устройства в Старом Свете. Отчасти она права, так как империи Старого Света, как правило, развивались в рамках постоянных заимствований друг у друга различных форм. Вместе с тем «избегание» термина «империя» перуанской исследовательницей ради «сохранения» ощущения эксклюзивности инкского государства не говорит о том, что в нем отсутствовали имперские формы и стратегии. На отсутствие этого термина в монографии Ростворовски де Диес Кансеко обратил внимание в своей рецензии на эту работу и известный американский археолог Алан Колата (Kolata \& de Diez Canseco, 2000).

2 До сих пор язык кечуа является самым распространенным индейским языком Южной Америки. На диалектах кечуа говорит по самым скромным подсчетам от 8,5 до 10 млн человек (Adelaar \& Muysken, 2004, p. 168). 
как бы располагалось на воображаемой оси, проходящей от острова Солнца на оз. Титикака до Кахамарки на севере Перу.

Но формальным центром империи был город Куско, что означало «пуп». Превращение центра империи в центр мира является типичным примером постулирования государства как империи. Эта идея может быть реализована не только в территориальном, но и историческом измерениях. Достаточно вспомнить, что Лондон, как имперский центр и центр мира, подкреплен самим фактом существования там Гринвичской обсерватории. Римская империя также имела свой центр мира ${ }^{1}$. Потом к нему добавился альтернативный центр - Константинополь. Москва также постоянно пыталась определить историческую значимость через «перенос» на себя функции сакрального и секулярного центра, что нашло отражение в формуле «Москва - третий Рим». Для подкрепления значимости ${ }^{2}$ этой концепции рядом с Москвой основывается в середине XVII в. монастырский комплекс Новый Иерусалим, призванный воссоздать ряд священных памятников Палестины ${ }^{3}$.

Административная модель инкской империи строилась на сочетании патриархальных традиций с бюрократическими, основанными на четких математических принципах развитой фискальной системы и особой культурногеографической структуре империи. Патриархальные традиции продолжали сохранение дуальной структуры общества, поделенного на две половины. Эти половины (Ханан и Хурин) существовали на уровне городов, поселков, отдельных общин и т.д..

Страна делится на четыре огромных региона - суйу (Чинча-суйю (северозапад), Колья-суйю (юго-восток), Кунти-суйю (юг) и Анти-суйю (север)), управляемых близкими родственниками Верховного инки (Сапа инка). Этих правителей называли апа. В свою очередь каждая из четырех частей состояла из провинций (сайя), которые также руководились губернаторами (токрикок) членами инкского рода. Каждая провинция, согласно дуальному принципу, подразделялась на Хурин и Ханан сайя. В отдельных случаях, ряд провинций делились на три сайя. Каждая сайя в идеале должна была состоять из 10000 налогоплательщиков.

По мнению российского археолога и специалиста по андским цивилизациям Ю. Березкина, «инки - это творцы продуманной социально-экономической и административной системы, с помощью которой им удалось в неви-

1 До сих пор существует фраза, подчеркивающая центростремительные силы этой империи: «Все дороги ведут в Рим». Но это не только дань дорожному строительству, но и указание на универсальность Рима, на котором все замыкается в государстве. Куско было таким же центром, из которого во все стороны расходились мощеные дороги. При отсутствии тягловой силы и колесного транспорта, дороги в Тауантинсуйу служили исключительно для имперских целей: переброски войск, передачи информации и т.д..

2 Концепция Москвы как преемницы Рима родилась задолго до того, как Россия превратилась в империю, но активизировалась именно в период расцвета империи в XIX в.

3 Эта традиция была продолжена и в наше время созданием в Москве в районе Отрадного Нового Иерусалима, представляющего собой комплекс храмовых построек, символизирующих четыре основных религиозных системы в России: православие, ислам, буддизм и иудаизм. 
данных прежде масштабах мобилизовать и целенаправленно использовать трудовые ресурсы своей страны. Обладая многими важнейшими признаками всех империй с одной стороны, и всех древних обществ - с другой, инкское государство отличается вместе с тем и рядом неповторимых особенностей. Возникает желание назвать его самым развитым из архаических и самым архаическим из развитых» (Березкин, 1991, с. 12).

Помимо следования патриархальной традиции инки создали уникальную фискальную систему, способную контролировать все аспекты общественной жизни в империи (McEwan, 2006, pp. 114-115). Без внимания и учета не оставалось ни одно домохозяйство. Десять домохозяйств составляли фискальную единицу, находящуюся под контролем специального чиновника - чунка камайока. Пятьдесят домохозяйств объединялись в следующую группу, которую контролировал писка чунка камайок. Эти две должности не были наследуемые, в отличие от тех, кто руководил большим числом домохозяйств $100,500,1000,5000$ и наконец 10000.

Но в обязанности чунка камайока и писка чунка камайока входили не только фискальные обязанности. Он должен был следить за все происходящим на вверенной ему территории: как едят крестьяне, как одеваются, хорошо ли ведут себя и т.д.. В случае каких-то чрезвычайных обстоятельств с него будет спрошено по всей строгости. От закона не освобождались и высшие должностные лица - кураки. В отдельных случаях требования к ним был намного стороже, чем к простым общинникам.

В сложные периоды войн, неурожаев, стихийных бедствий и т.д. общинник всегда мог рассчитывать на то, что он получит помощь от государства в виде одежды, пропитания, орудий труда и т.д..

Высшие кураки отвечали не только за сбор налогов, они обязаны были следить за общественными кладовыми, состоянием дорог, подвесных мостов, работой почтовых станций ${ }^{1}$ и т.д..

Во многом инкская империя функционировала как хорошо отлаженный часовой механизм, в котором все указывало на крайнюю форму имперскости.

Мы, собственно, и начали раскрывать некоторые характеристики имперскости на примере инков, чтобы как можно дальше отойти от империй в Старом Свете, поскольку посчитали, что в некоторой степени они повторяли друг

1 Почтовая служба инков представляла собой достаточно развитую систему. В государстве насчитывалось от до 2000 почтовых станций - тамбос. Они располагались на расстоянии 15-20 км.. Расстояние варьировалось в зависимости от рельефа местности. В этих станциях постоянно жили гонцы - часки, которые могли бежать с огромной скоростью, способные доставлять информацию из одного конца империи в другую за очень короткий срок. Расстояние от Лимы до Куско (650) км., как сообщали хронисты, гонцы преодолевали за 3 дня, в то время как всаднику потребовалось бы больше недели (Cobo, 1979, pp. 228230). Почтовую службу у инков можно было бы сравнить с ямской системой в России, с той лишь разницей, что во многом у инков эта служба функционировала несколько эффективней, несмотря на то что для этих целей в России использовались лошади. 
друга ${ }^{1}$. Все не так с инками, они «изобретали» свою империю, основываясь на опыте других доколумбовых цивилизаций, инкорпорировали все достижения других индейских империй (Уари, Тиуанако и т.д.).

Одним из важнейших символов ${ }^{2}$, направленных на формирование имперскости, в Старом свете, как нам кажется, был троп «сада».

\section{В тени садов империи}

Имеется множество причин, по которым «сад» оказывается важнейшим элементом категории «империя», наполняет и в некоторой степени оформляет ее особым способом. Этот троп, как и многие другие, оказывается тем местом, где мифология империи и имперские принципы пространства тесно переплетаются. Но, прежде чем в полной мере перейдем к европейским империям Нового времени, попытаемся отыскать в культуре инков нечто соответствующее нашему пониманию сада ${ }^{3}$. Сразу же оговоримся, что задача очень сложная, так как первые испанские хронисты больше интересовались золотом, чем какими-то бытовыми делами инков. Конечно, имеются упоминание садов и огородов у инков, но они фрагментарные.

И в то же время есть нечто, что проясняет садовую парадигму империи. В этом нам как нельзя лучше помогают мифология и модели пространства у инков. Имперский миф у инков сконцентрирован на поиске предками (первыми инками) плодородной земли - четыре пары первопредков путешествуют по стране. В руках у одного из них Золотой жезл, который он время от время втыкает в землю, чтобы определить качество почвы. Дойдя, до долины Куско, они нашли место, где жезл главного героя вошел глубоко в землю. Здесь и было решено основать их поселение. Инки принесли с собой семена маиса, которые в этом месте и посеяли (Sarmiento de Gamboa, 2007, pp. 68-71; Steele \& Allen, 2004, pp. 60-61).

Как уже говорилось, Куско, согласно имперской идеологии, являлось не просто столицей государства, это еще и сакральный центр мира, что подкреплялось самыми разнообразными способами, и не только потому, что здесь располагалась резиденция Великого Инки. Из Куско во все стороны веером расходились дороги. Значимость Куско и движения по этим дорогам

1 Хотя в Европе в Новое время эталонным примером был Рим, однако, не обошлось без внимания к таким империям как Османская, Цинская и т.д..

2 Мы не считаем его главным, но вместе с тем полагаем, что он играл очень важную роль утверждения значимости монархии как мирового центра.

3 Задача непростая, так как мы не дали определения термину «сад», посчитав, что оно усложнит и запутает наше повествование. Римляне подразделяли «hortus» - «огород-сад» и «horti» - «сад-парк». В любой культуре, в основе которой лежит земледелие, понятие «сада», как символа благополучия, процветание будет восходить к концепции возделывания земли, вспахивания, проведение первой борозды и т.д.. В русской культуре концепция сада имеет самые разнообразные аспекты. В русской культуре концепция сада в разные периоды принимала самые различные формы. По сути трансформации концепции «сада» посвящено произведение А. Чехова «Вишневый сад», в котором эта смена культурной парадигмы и лежит в основе сюжета произведения. 
подкреплялось неким негласным этикетом: идущий в столицу должен был проявить почтение идущему из столицы, так как сам факт пребывания в столице повышал важность человека ${ }^{1}$. Житель Куско, что определялось его одеждой, считался более высоким статусом по самому месту проживания. Из Куско во все стороны расходились и специальные линии - секе, вдоль которых располагались ирригационные каналы, святилища и т.д.

Ну и, наконец, в столице был построен главный храм государства - Кориканча (кеч. «золотой двор»), посвященный Солнцу и Луне, а также верховным божествам Пачакамаку и Виракоче. При храме, составляющим основу этого комплекса, имелся и особый сад, где все было сделано из золота в натуральную величину²:

Тот огород, который сейчас служит для обеспечения монастыря овощами, во времена инков являлся садом из золота и серебра - такие сады имелись в королевских домах королей; в них находилось множество трав и цветов различного происхождения, множество малых растений и больших деревьев, множество больших и малых, свирепых и домашних животных и пресмыкающихся, которые ползают, как змеи, большие и маленькие ящерицы и улитки, бабочки и птицы и другие более крупные воздушные пернатые - каждая вещь стояла так и на том месте, которое более всего делало ее схожей с изображаемой ею натурой.

Было [там] большое кукурузное поле и растение (semilla), которое они называют кинуа, и другие овощи, и фруктовые деревья со своими плодами, целиком из золота и серебра, повторявшие натуру. В доме имелись также изготовленные в золоте и серебре груды дров, как те, что находились в королевском доме; [там] были также большие фигуры мужчин, и женщин, и детей, отлитые из того же самого [металла], и много житниц и амбаров, которые они называют пирва, все для украшения и большего величия дома своего бога Солнца (Инка Гарсиласо, 1974, с. 194).

Гарсиласо де ла Вега также поясняет, что мастера золотых дел ежегодно присылали свои изделия в главный храм, так что Кориканча выполняла еще и функцию особого хранилища, содержащего диковинные предметы со всей империи.

Другими словами, Кориканча была своеобразным местом, призванным аккумулировать все разнообразие и мощь империи ${ }^{3}$. С подобной же моделью

1 В качестве сравнения уместно вспомнить «Песню о Москве» муз. Т. Хренникова, слова В. Гусева из кинофильма «Свинарка и пастух» (1941): «И в какой стороне я не буду, // По какой ни пройду я траве, // Друга я никогда не забуду, // Если с ним подружился в Москве». В песне подчеркивается не факт встречи, а то, что она происходит именно в Москве. В первом куплете говорится и о том, что «как речки встречаются в море, так встречаются люди в Москве». Москва в песне предстает своеобразным центром, куда стекаются люди, встреча здесь наделена особыми свойствами.

2 Мы не знаем, был ли при храме и реальный сад, так как испанцев не интересовали такие аспекты. Но по косвенным данным можно судить, что все-таки при храме располагалось нечто напоминающее сад или огород, снабжавшийся водой из специального водопровода, который перестал функционировать при испанцах, после чего огород высох.

3 Советская модель империи близка по символике инкской. Достаточно вспомнить фонтан «Дружба народов» на ВДНХ, сооруженный в 1954 г.. Основу композиции составляют 16 женских фигур, символизирую- 
Journal of Frontier Studies. 2022. No 1 | ISSN: 2500-0225

Imperial Practices | https://doi.org/10.46539/jfs.v7i1.373

аккумуляции всего, что имелось в империи, мы встречаем и в Древнем Китае в правление первого императора Ши-хуанди:

[Ши-хуан] собрал оружие со всей Поднебесной в Сяньян и выплавил из него колокола и вешала для них, а также двенадцать металлических фигур весом в тысячу даней каждая, которые установил в своих дворцах. [Он ввел] единую систему законов и измерений, мер веса, емкости и длины, для повозок установил одинаковый ход, в письме - единое начертание иероглифов.

Земли [Цинь] на востоке теперь простирались до моря и Чаосяни; на западе достигали Линьтао и Цянчжуна; на юге доходили до Бэйсянху; на севере тянулись вдоль Хуанхэ, служившей им заслоном, и далее по горам Иньшань доходили до Ляодуна. [Ши-хуан] переселил в Сяньян со всей Поднебесной сто двадцать тысяч знатных и богатых семей. Все храмы предков, дворец Чжантай и парк Шанлинь располагались на южном берегу реки Вэй.

Каждый раз, когда Цинь сокрушало власть кого-либо из владетельных князей, [циньский ван приказывал] зарисовать устройство его дворца и строить [подобный же] дворец на возвышенности к северу от Сяньяна, так, чтобы дворец этот был обращен к югу - к реке Вэй. [Поэтому] от Юнмэня на восток вплоть до рек Цзиншуй и Вэйшуй [всюду высились] дворцы и дома, соединенные переходами поверху и понизу и огороженными дорогами. [Он] заполнил дворцы красавицами, наполнил палаты колоколами и барабанами, захваченными у князей (Сыма Цянь, 2003, с. 65).

Империя в своем развитии сочетает центростремительные и центробежные силы. С одной стороны, она аккумулирует в центре символы покоренных народов, а с другой, она водружает на периферии свои символы, свои памятники. Как сообщает Гарсиласо де ла Вега, храмы, подобные Кориканча были сооружены и в других городах империи (с. 194). Когда четвертый инка Майта Капак взошел на трон и начал править, он женился на дочери правителя народа кольяуа. Пожелав встретиться с ее родственниками, он отправился к ней на родину в Кольясуйу. Чтобы встретить Инку и его жену с почтением, жители провинции построили для них дом из меди, по образцу Кориканчи (Cobo, 1979, p. 119).

Этот обмен репликами является сутью имперских процессов. Центральная власть утверждает свое могущество над покоренными народами, собирая в центре их реликвии, или воспроизводя символы их власти у себя. В свою очередь она аккультурирует и социализирует включенные в свою

щих союзные республики. Цвет фигур золотой, что подчеркивало величие этой композиции, ее помпезный вид. Все фигуры располагались вокруг центральной композиции, символизирующий сноп. Каждая из фигур изображена с сельскохозяйственными дарами своей республики. Достаточно интересно то, что имперскость этого сооружения была понятна (на подсознательном уровне) и простым россиянам. Об этом свидетельствует традиция ежегодного купания в фонтане бывших десантников на День ВДВ. По сути, купание в фонтане «Дружба народов» - это акт приобщения к имперскости, доказательство своего могущества, а попытки залезть на статуи, изображающие соседние, теперь уже независимые республики, - это символический акт их покорения. Об этом же свидетельствуют попытки водрузить свои флаги на эти статуи. 
империю народы, репродуцируя себя через свои символы власти или победы. И чем величественней эти символы, тем значимей выглядит сама империя.

Другими словами, имперский сад (в разных его формах) - это, с одной стороны, концентрированное выражение аграрного характера империи, а с другой - символ, призванный воплотить в своем локусе весь топос империи, стать своеобразным центром, аккумулирующим в себе все многообразие империи.

Но это, если смотреть на сад в его внерегиональном аспекте. Имперский сад Старого света, и особенно в Европе, развивался в несколько ином направлении. На это очень хорошо указывает Плиний в его «Естественной истории»:

Осталось перейти от растений к разведению садов - тема, рекомендуемая как по своей собственной природе, так и в силу того, что античность выражала свое высочайшее восхищение садом Гесперид и царей Адониса и Алкиноя, а также висячими садами, будь то построенные Семирамидой или Киром, царем Ассирии, о работе которого мы поговорим в другом томе. Цари Рима действительно возделывали свои сады собственными руками; на самом деле именно из своего сада даже Тарквиний Гордый отправил жестокое и кровожадное послание своему сыну. В наших Законах Двенадцати Таблиц слово «ферма» никогда не встречается - слово «сад» всегда используется в этом смысле, а сад обозначается «родовым поместьем». Следовательно, саду придается даже некое ощущение святости, и только в саду и на Форуме мы видим статуи сатиров, выступающие в качестве талисмана против колдовства завистников, хотя Плавт говорит о садах как о находящихся под опекой Венеры. В наши дни под названием садов люди действительно воплощают роскошь обычных ферм и загородных домов в черте города. Эту практику впервые ввел в Афинах ценитель роскошной простоты Эпикур; до его времени не существовало обычая иметь загородные жилища в городах... Действительно, низшие классы в городе ежедневно любовались сельскими пейзажами с помощью имитации садов в своих окнах, до того времени, когда отвратительные кражи в бесчисленном количестве заставили их закрыть весь вид ставнями (Pliny, 1967, Vol 3, pp. 451-452).

Другими словами, у римлян ко времени Плиния, а вероятно и раньше, уже была четкая картина того, как должен выглядеть сад. Как указывает петербургский исследователь В.П. Поршнев, «Римские сады, с точки зрения планировки и оформления, не были абсолютной инновацией. Образцом для римлян служили царские сады в Александрии Египетской. Лукулл посетил Александрию с дипломатической миссией в 87 г. до н. э. и прожил в городе всю зиму в одном из царских дворцов» (Поршнев, 2020, с. 71).

Но именно в Древнем Риме сад из греческой или восточной традиции ${ }^{1}$ восходящий больше к мифологии, чем к реальным практикам, начал приобре-

1 Греческая традиция концепции сада восходит в свою очередь к персидской, точнее к Ахеменидам. Даже само слово, употребляемое греками и римлянами для сада - paradeisos - берет свое начало в персидском языке (староперс «paridaida»), обозначавшим самые различные понятия - склад, виноградник, рощу деревьев. Персы свозили в такой сад диких животных, на которых правитель любил охотиться (Luttikhuizen, 1999, pp. 3-5). Легко заметить, что слово «парадиз» во многих европейских языках вошло в значении рая. 
тать черты имперского сада. Одновременно на него влияют самые различные формы: аграрная традиция (сад, как место полезных растений), классическая традиция греческого сада и имперская императива. Сад - это Locus amoenus место единения с природой, идиллия, ну или пасторалия, своеобразная визуальная эклога ${ }^{1}$, наполненная статуями, призванными указать человеку, что он находится в особом мире идиллии, сближающей его с золотым веков древности. Римляне наследуют эту традицию у греков. Но в процессе формирования империи формы римского сада начинают меняться. Как замечает Поршнев, «...забота о досуге горожан отступает на второй план по сравнению с желанием продемонстрировать престиж и могущество монархического государства. Ранее эта тенденция проявилась в грандиозном проекте Нерона, пожелавшего превратить центр Рима в единую парковую зону, площадь которой должна была составлять от ста до двухсот акров» (Там же, c. 71).

Мы уже писали, что одной из характерных черт имперского сада является его свойство аккумулировать объекты из разных регионов империи и даже изза ее пределов. Со временем в Риме начинают осуществляться подобные практики. И речь идет не сколько о собирании разнообразных статуй греческих богов и героев, хотя и это в некоторой степени можно отнести к тому же феномену. Постепенно имперские сады заполняются и другими объектами. Типичным примером могут служить сады Саллюстия, которые считаются образцом паркового искусства:

В садах Саллюстия Октавиан Август велел установить египетский обелиск (Obeliscus Sallustianus)... Еще два обелиска, вывезенные из Египта в качестве трофеев римского народа, были поставлены перед его Мавзолеем на Марсовом поле. Калигула распорядился воздвигнуть подобный же обелиск в садах Агриппины-Домиции (ныне он стоит перед собором Св. Петра) (Поршнев, 2020, c. 72).

B XVII-XIX вв. на территории, где располагались сады Саллюста, были найдены в изобилии различные древнеегипетские скульптуры (Hartswick, 2004, pp. 130-140).

Как сообщает Плиний в своей естественной истории, в этих садах имелась также и могилы двух очень высоких людей якобы под три метра ростом, живших во времена Цезаря (Pliny 1967, V 2 : 569). Некоторые высокие люди, как диковинки, привозились в Рим со всего света ${ }^{2}$. Осмелимся предположить, что и множество других уникальных предметов доставлялись в сады римских императоров и сенаторов.

Но не будем подробно останавливаться на римских садах, чтобы не уйти слишком далеко от изучаемого вопроса. Для нас важно отметить следующий

1 Locus amoenus мы находим и на картинах китайских художников, изображавших беседы философов или ученых на природе.

2 Плиний сообщает, что очень высокий человек (9 футов, 9 дюймов) был привезен из Аравии. Его звали Габбара (там же). 
момент в организации имперского пространства: сад - это особое место, повторяющее античную традицию (персидскую, египетскую, древнегреческую), оно - место сосредоточения не только природных символов, но и предметов, связанных с другими территориями, народами и культурами․․

Во многом такая парадигма начала проявляться и в парках Нового времени, берущих свое начало в период Ренессанса., когда начинает доминировать концепция, восходящая еще к персидской символике сада как райского места. Это подкреплялось еще и исламской традицией, в которой данная концепция также доминировала (См.: (Gharipour, 2017)). Кроме символики рая, в исламской традиции превалировала и символика величие власти правителя (Ruggles, 1994).

\section{Англия как сад}

Здесь мы подходим к очень важной и интересной теме имперского сада в Новое время. На наш взгляд, именно в указанный период это явление и приобретает все характерные черты имперскости, даже когда сад выступает в качестве частного сада и, казалось, бы перестает быть идеологией или политикой, и превращается в увлечение, но остается специфичным явлением, сохраняющим в себе все черты имперскости.

Сложно сказать, что лежит в основе этого феномена в Новое время. Уж слишком много предыдущих традиций влияли на него. Д. МакКрекен считает, что

Современные ботанические сады зародились в результате интеллектуального движения восемнадцатого века, известного как Просвещение. Этот век Разума сумел объединить чувство эстетического вкуса с рациональным отношением к научным изысканиям. Ботанические сады олицетворяли эту философию: они сочетали в себе величие пейзажного движения. Они символизировали новую эру мира, которая воцарилась в Европе между 1760-ми и 1790-ми годами, и давали практическое воплощение идеям великого шведского ботаника Карла Линнея (McCracken, 1997, p. 1).

И хотя с некоторыми выводами МакКрекена можно поспорить, но в целом он прав, так как именно сочетание эстетических принципов и научной составляющей было и остается отличительной чертой имперского сада ${ }^{2}$. Уточнения

1 В этом плане примечательно, что именно обелиск становится таким символом, так как отражает ту же самую концепцию триумфа царской власти. Но теперь чужой триумф (древнеегипетского правителя) призван подтверждать величие правителя римского. Но в этом пространстве власти находится место не только для триумфа правителя. Найдены на территории садов самые разные скульптуры, в том числе и большая статуя гиппопотама, сделанная из розового мрамора. Интересны упоминания Плиния и о высоких людях, и их могилах на территории сада. Для имперского сада важны не только предметы, символизирующие славу, победу государства, но и особые курьезы, диковины, которые бы свидетельствовали о разнообразии флоры, фауны и обитателей империи.

2 Здесь мы не разделяем два разных вида имперского сада - сад, как рекреационное место (парк), и сад как научное учреждение, выполняющее важную функцию изучения. В Новое время эти формы очень часто перетекали одна в другую. Например, ботанический сад часто использовался в рекреационных целях а парк мог быть местом, где росли уникальные растения, привезенные с других стран. Конечно, ботани- 
требует лишь тот момент, что не только Просвещение повлияло на формирование концепции имперского сада ${ }^{1}$. На феномене сада сказалось и активное взаимодействие ряда европейских государств с Востоком - прежде всего с мусульманскими странами: в Испании, Северной Африке и Османской империей. Эти страны оказывали влияние как на эстетические каноны сада, так и на научную составляющую, так как благодаря переводам античных научных тестов на арабский, они дошли и до «просвещенного» Запада. Ряд этих текстов касались именно растительного мира.

Огромную роль в «становлении» имперского сада в Европе сыграла и Венецианская республика, так как именно в период ее существования и закладывались многие аспекты дальнейшего экономического могущества европейских держав.

Следует также добавить, что и научная составляющая имперского сада оказывалась воплощением ряда самых различных идей, как практического, так и теоретического характера. Не стоит забывать, что сама эпоха Великих географических открытий во многом имела ботанический характер, так как была инспирирована частично поиском путей в страны-производители специй. Но колониальный характер Британской империи складывался не только на основании захвата Индии и превращение ее в свою колонию, но и на основе сахарных плантаций на Карибских островах. Сахар оказался не менее мощным оружием в достижении имперского могущества Британии (Mintz, 1986)) $)^{2}$, чем чай или опиум, получаемые из Индии и Китая. К этому списку со временем добавлялись все новые и новые растения, формировавшие современную капиталистическую систему (См.: Baber, 2016; Brockway, 2002; Romaniello, 2016).

Имперский сад имел самые разнообразные формы и функции в зависимости от конкретного периода своего существования. Но при всем своем своеобразии это был целостный институт, призванный обслуживать интересы империи в виде накопления ценной продукции или материалов и нового знания. Не стоит забывать, что помимо собственно прагматичных целей обретения нужного сырья для фитотерапии и редких пищевых растений, сад играл и очень важную роль утверждения идеологической составляющей империи. Сад, как мы уже говорили, символически фиксировал центр империи, являясь своеобразной аллегорией райского сада (Nicosia, 2017). «Перенос» символиче-

ческий сад, как правило, выполнял утилитарную функцию.

1 Говоря про имперский сад, не стоит забывать, что у него было множество различных национальных форм, каждая из которых черпала свое «вдохновение» в самых различных идеях и практиках. Так имперский сад во Франции в своем основании оказался столь же рационален, как и британский, а возможно и больше, но его кажущаяся картезианская рациональность продиктована совершенно иными принципами, восходящими в большей степени к традициям средневековой архитектуры фортификационного характера (Mukerji, 1997, p. 39). Но несмотря на эту особенность, французский сад не переставал от этого быть имперским садом, так как помимо архитектурного своеобразия в нем проявлялись и другие черты, связывающие его с колониальной историей этой страны.

2 О роли сахарного тростника в формировании рабовладельческой системы в Америке мы писали в одной из предыдущих работ (Якушенков \& Якушенкова, 2021, сс. 18-22). 
ского центра мира на свою территорию делал империю более могущественной и легитимной в самых различных аспектах.

Конечно, не обязательно, чтобы этот «центр» располагался именно в центре столицы, хотя в отдельных случаях и это обретало реальное воплощение. Сад, как и рай, мог находится и на периферии, но главное, чтобы он был частью империи. Как отмечает М. Никозия, «Эдем одновременно и центр, и периферия, дом и колония» (Nicosia, 2017, p. 52). И в этой сентенции нет никаких противоречий, так как империя - это в некоторой степени сеть, связывающая центр с периферией, чем больше этих нитей, тем могущественней центр. Отсюда сады на периферии множатся, но не перестают терять символическое значение рая. Наоборот, они призваны подпитывать центр, «снабжая» его всем необходимым. Из 126 садов Британской империи (XVI-XIX вв.) 100 садов располагалось в колониях. Четыре самые крупные из них находились в Калькутте, Маврикии, Цейлоне и Тринидаде. Все они имели статус «Королевского ботанического сада». Примечательны как их география, так и история. Эти сады как бы располагались в разных частях Света. У каждого из них особая имперская история, неразрывно связанная с формированием Британской империи. Так сад в Калькутте был основан в 1787 г. полковником Ост-Индской компании Робертом Кидом (Robert Kyd). Особо хотелось бы подчеркнуть те цели, которые преследовала компания, создавая этот сад. В своем письме руководству Компании, он указывал, что такой сад мог бы стать основой продвижения важных культур в Индию, что в свою очередь бы сломало монополию голландцев на некоторые культуры. Среди подобных растений Кид упоминал корицу, кардамон, черный и белый перец, мускат, гвоздику и ряд других ароматических специй (Chatterjee, 1948, p. 362). Особое внимание уделялось вопросам акклиматизации тика, ценная древесина которого активно вывозилась в Европу. Надо отдать должное полковнику Киду, так как среди названных им причин для основания ботанического сада имелась одна достаточно веская и благородная идея - содействовать акклиматизации новых растений, способных помочь ликвидировать голод среди местного населения в Бенгалии. Он намеревался ввести в регион новые пищевые культуры: саговую пальму с Суматры и финиковую пальму из Персии (Thomas, 2006, pp. 167-169).

В действиях полковника не было ничего удивительного. Садом, в котором акклиматизировались редкие тропические растения, владел и у Уоррен Гастингс - первый генерал-губернатор Бенгалии․․ Инициатива Р. Кида нашла полное понимание как в самой Бенгалии, так и в Британии, так как действия полковника соответствовали политике Ост-Индской компании и Британской империи в целом. Р. Кида активно поддержал знаменитый натуралист и президент Лондонского королевского общества Джозеф Бэнкс, пользовавшийся уважением королевской семьи. Еще до своего назначения на должность прези-

1 После того, как У. Гастингса отозвали в Лондон, Кид перевез часть растений из его сада в новый ботанический сад. 
дента, Бэнкс получил известность как участник первого кругосветного путешествия Кука, в которой он выполнял функцию ботаника. Еще будучи совсем молодым человеком Дж. Бэнкс активно общался с известным шведским натуралистом Карлом Линнеем. Дружил он и с соратником и учеником Линнея Даниэлем Соландером, с которым потом участвовал в кругосветном плавании Кука. Именно он, пользуясь вниманием со стороны Георга III, убедил последнего заняться активно развитием Королевского ботанического сада Кью1. Другими словами, действия Р. Кида совпали с теми тенденциями, которые происходили в это время и в самой Британии. Правильно было бы даже сказать, что его действия отражали тенденции, активно проявившиеся в метрополии.

Как и у сада в Калькутте, у других королевских садов была такая же имперская история. Например, сад в Маврикии явился отражением всей колониальной и имперской истории не только Британии, но и в целом Европы, так как первоначально в первой половине XVIII в. его основали еще французы, когда остров являлся французской колонией. Как и британцы в Калькутте, французы преследовали достаточно утилитарные цели, пытаясь акклиматизировать здесь необходимые им лекарственные и пищевые растения. Еще первый организатор этого сада засадил купленную им землю тутовыми деревьями для занятий шелководством. Но так как опыт этот оказался неудачным, он продал свою землю французской Ост-Индской компании и уехал с острова. Новые хозяева переориентировались на культуры, привезенные частично из Бразилии, а частично из Индии и Юго-Западной Азии. Среди новых культур ботанического сада ${ }^{2}$ появились мускатный орех, корица, гвоздика, душистый перец, индийский миндаль (Terminalia Catappa), саговая пальма, какао, мангостин и многие другие фрукты (The Botanic Garden of Pamplemousses, 1919, pp. 281-282).

Большинство этих садов в Азии, Африке или Америки постепенно превращались в разветвленную сеть, активно взаимодействующую друг с другом ${ }^{3}$. Везде, где бы не создавались подобные сады, они преследовали сразу несколько целей: выявление возможностей для получения растительного сырья - прежде всего специй, и для изменения ландшафта с целью получения максимальной прибыли. Конечно, не англичане и не французы первыми начали этот процесс - португальцы, и голландцы длительное время сохраняли приоритет в указанном вопросе ${ }^{4}$, но ко второй половине XVIII в. мир во многом

1 Хотя мы и говорили, что Сад (как центр мира/империи) необязательно должен находится в столице государства, но Сады Кью, напротив, находились если и не в центре Лондона, но в пределах городских окраин.

2 Он стал называться «Мон плезир» или «Ботанический сад Памплемус», по месту его расположения.

3 Но не только из периферии шли ценные образцы в центр. Ботанические сады в Лондоне аккумулировали самое необходимое и самое ценное, изучали растения и распространяли опыт и посадочный материал по своим колониям (Barnard, 2018, 2018, p. 45).

4 Мы не приводили примеры из истории португальских, испанских и голландских садов, чтобы не увеличивать и без того большой объем этого текста, но сразу же можно сказать, что история этих имперских 
оказался в таком состоянии, когда первые монополии на некоторое растительное сырье утратили свое значение. Биоразведка и усилия ботаников по акклиматизации нужных растений возымели свое действие.

Следует признать, что сад, в его имперском варианте, хотя и находился во многом в основании имперского фундамента, не утратил своей роли и после того, как империи перестали существовать. До сих пор ботанический сад выполняет важные функции: научные, образовательные, культурные и т.д..

\section{Сама садик я садила: имперский опыт России}

В этой части мы собираемся поговорить не о всех садах Российской империи. Здесь мы отдаем приоритет Астраханской губернии ${ }^{1}$, но и не забываем на ряд фактов по имперскому саду, касающихся Центра. И на это есть несколько причин. Прежде всего то, что 1721 - год провозглашения России империей - совпадает с рядом указов Петра I, направленных на становление института имперского сада в регионе. Другими словами, некоторые имперские практики предвосхищали империю, как бы изначально оформляли ее, создавая некоторый фон, на котором и выстраивалась основная стратегия развития. Если Российская империя была провозглашена 22 октября ${ }^{2} 1721$ г., то почти ровно за год до этого - 26 октября 1720 г. Петр I издает именной указ ${ }^{3}$ астраханскому губернатору Артемию Волынскому:

1. Завесть в Астрахани Аптекарский огород, также сделать аранжерею и держать вывозные из Персии деревья и травы (которые не могут в городе зимовать) и для приготовления трав, которые потребны в Аптеку, взять из Санктпетербурга в Астрахань Аптекаря да огородника.

2. Которые виноградные сады при Астрахани, из того винограда делать горячее вино, а вместо того для вин завести же виноградные сады в Гребенях; и того ради послать туда для пробы мастеров тех, которые в Астрахани, и чтобы оные там обыскали тому пригодные места, а из готового сделали бы пробу.

8. Присылать во все годы в Санктпетербург чинаровые и ореховые деревья...

9. При Астрахани и в других местах, где степи, сеять дубовые желуди для лесов таким образом, как заводят леса в Европе (ПСЗРИ-1, 1830, Т. 6, сс. 251-252).

садов, особенно голландских столь же показательна, как и британских. Мы сосредоточились на британской системе, так как она оказалась самой мощной и самой живучей из всех систем, просуществовав на протяжении нескольких веков.

1 Астраханская губерния была выбрана по ряду причин. Во-первых, этот материал предназначался для Петровских чтений, проходящих в Астраханском государственном университете в ноябре 2021 г., во-вторых, эта работа - своеобразный hотmage истории региона, о которой жители края не имеют никакого представления, и, наконец, развитие садоводства в крае представляется нам типичным примером отношений центра-периферии.

2 Мы специально сохраняем здесь старый стиль, так как на тот момент восприятие мира и особенно окружающей природы происходило в соответствии с этим календарем.

3 Часть пунктов этого указа касалась не только садов, но и других аспектов биоразведки: ввоз лошадей и быков из Персии, поиск новых продуктивных пород овец и приглашение овчаров из Шлезии, скупка кож калмыцких быков, отлов и направление в столицу «курьезных» животных, засол рыбы осетровых пород и многие другие вопросы, не связанные с садами. 
Конечно, неверно полагать, что все вышеупомянутые указы были нововведением. Петр I еще до провозглашения России империей уделял огромное внимание развитию аграрного сектора в Астрахани. Во многих отношениях Астрахань была особым краем с уникальными природными характеристиками. Ряд продуктов, производимых здесь, имели стратегическое значение для государства. К ним в первую очередь относится виноград, который начали выращивать в регионе еще в начале XVII в. В именной росписи 1700 г. Астраханскому воеводе Мусину-Пушкину указывается, что в Москву ежегодно необходимо поставлять 1000 гроздей винограда, а лишь остаток разрешалось продавать на месте (ПСЗРИ-1, Т. 4, с. 39). Огромное значение имело и производимое в Астрахани вино, хотя оно не пользовалось большой популярностью, так как чаще всего попадало в Москву или Петербург уже не в лучшем виде, по причине длительной транспортировки в повозках, во время которых вино постоянно сбалтывалось из-за тряски на ухабах.

Другим особым продуктом считались арбузы, по поводу транспортировки которых в столицу Петр I также дал воеводе особые указания.

Но не только к пищевым продуктам будущий император проявлял такое внимание. Ряд деревьев он относил к ценному сырью, и за порубку некоторых полагался или высокий штраф, или даже смертная казнь. Среди подобных деревьев были тутовые деревья или шелковица ${ }^{1}$, которые в регионе начали сажать еще в правление Алексея Михайловича, и регулярно из Астрахани поставляли небольшое количество шелка, произведенного местными мастерами.

В своем наказе царь повелевал:

В Астрахани велеть, Великого Государя в садах, и у Астраханских жилецких людей, у которых есть в огородах тутовые деревья, переписать, и вновь приискав угожие места, для шелкового промыслу, велеть тутовые сады заводить большие, чтобы шелкового дела, перед прежними годами было больше, и учинить в том при себе прибыль большую, и о том тутовом дереве велети в Астрахани учинить заказ крепкой под смертною казнью, чтобы того тутового деревья, отнюдь никто не сек и ничем не пустошил; а велеть тутовые деревья в Астрахани разводить наемными людьми; а наем тем людям велеть давать из казны Великого Государя, по своему разсмотренью, как бы Великого Государя казне было прибыльнее, и во всякой Великого Государя казне искать прибыли, в деньгах и в хлебе и в рыбных промыслах, и тутовый сад и виноград развесть, чтобы шелковый завод и виноградные сады завесть в добрых местах, а в худых местах не заводить, где виноградного плода не чаять, и городьбу укрепить, и о всем учинить по своему разсмотренью, и о том писать к Великому Государю (ПСЗРИ-1, Т. 4, с. 42).

В значительной степени действия Петра были бессистемны и во многом продолжали традицию, заложенную еще до него. Он лишь фиксировал и

1 Может быть именно этим интересом к шелковице был вызван тот факт, что Петр I посадил якобы это дерево в одном из частных садов в Лондоне в 1698 г., о чем и свидетельствует памятная табличка на русском и английском языках, установленная не так давно в этом парке (Russkiy Mir, 2018) 
подталкивал местные власти к действиям по поддержанию этой сферы деятельности. Так виноград, как уже говорилось, начали выращивать еще в 1613 г. Инициатором выступил монах, родом из Австрии, который еще ребенком попал в плен к туркам, откуда его и выкупили русские. Лозу ему привезли из Персии, и она не только принялась, но и начала приносить урожай (Якушенков \& Палаткин, 2020, сс. 254-255). И не случайно здесь проявилась эта гибридность, так характерная для империй: православный монах австрийского происхождения и лоза, привезенная персидскими купцами из Шемахи. Астрахань изначально символизировала имперскость, даже до ее провозглашения. Она проявлялась как империя, она влияла на формирование империи и функционировала как имперская территория ${ }^{1}$ Уникальность края хорошо заметна по тем продуктам, которые увидел секретарь Голштимского посольства А. Олеарий на столе во время приема:

виноград, яблоки, дыни, персики, абрикосы, миндаль, два рода изюму (один из них представлял небольшие белые и очень сладкие ягоды без косточек), лущеные большие грецкие орехи, фисташки, всевозможные в сахаре и меду вареные индийские чуждые фрукты стояли на столе, покрытые шелковыми платками (Олеарий, 2003, с. 354).

Олеарий нашел местный фрукты превосходными. Ну а обилие их тоже поразило его (Там же, с. 346). Поэтому неудивительно, что регион имел особый статус и воспринимался как всероссийская житница ${ }^{2}$.

Но, вне всякого сомнения, Петр I сделал очень много для того, чтобы закрепить за Астраханью этот статус. В отчете Государственной экспедиции ${ }^{3} 1798$ г. по изучению виноделия в Астраханской губернии подчеркивается, что до времени правления Петра Первого все местные казенные или частные сады были маловажны для государства (ГААО. Ф. 13. Оп. 1. Д. 1879. л. 2).

Неудивительно, что именно в Астрахани заложили третий в России Аптекарский огород, призванный стать экспериментальной площадкой для внедрения в регионе различных ценных пищевых растений, а затем и в другие места страны. На должность директора Садовой конторы назначили француза Посьета (Possuet) ${ }^{4}$ В течение 37 лет Посьет занимался разведением садов. В этот период времени Астрахань сформировалась как крупнейший и единственный центр российского виноделия (Баллас, 1895, с. 195).

1 Само присоединение Казанского и Астраханского ханств уже ознаменовало движение Московского княжества к Российской империи.

2 Но не только продукты растительного происхождения формировали этот статус региона. Значительную роль играли и рыбные запасы, и животноводческие ресурсы края. В XVII - XVIII вв. это подкреплялось еще и уникальной фауной, особенно пернатыми, и прежде всего ловчими птицами. Одновременно с Аптекарским огородом в Астрахани был основан и Птичий двор.

3 Экспедиции государственного хозяйства, опекунства иностранных и сельского домоводства. В отчете экспедиции были представлены фрагменты документов, которые на сегодняшний день не сохранились. Они подтверждают, что первый казенный сад в Астрахани появился в 1613 г.

4 Посьет приехал в Астрахань еще до основания Аптекарского огорода. Изначально он должен был направится в Азов для разведения там винограда, но Азов на тот момент был возвращен османам, и виноградарь был послан в Астрахань. 
Новый этап в развитии виноградных садов наступил в 1735 г. и продолжился до 1767 г.. На момент 1735 г. в Астрахани имелось 18 виноградных садов, в которых разводили виноград нескольких сортов (ГААО. Ф. 521. Оп. 1. Д. 1. л. 1). Но все изменилось с приездом серба ${ }^{1}$ Ивана Андреевича Паробича, который был назначен директором Садовой конторы по распоряжению кабинет-секретаря императора И. А. Черкасова (ГААО. Ф. 521. Ол. 1. Д. 1. л. 11). Новый директор с энтузиастом взялся за перестройку работы конторы. Он высадил приведенные с собой венгерские лозы и заложил несколько новых виноградников, увеличил территорию Конторы (ГААО. Ф. 521. Ол. 1. Д. 32. л. 5-32), наладил ежемесячную отправку фруктов, овощей, вина, французской водки ко двору императора (ГААО. Ф. 521. Оп. 1. Д. 3. л. 98).

Сложно сказать, был ли какой-то сельскохозяйственный опыт у Ивана Паробича, да и чем он занимался раньше, но он показал себя очень хорошим организатором. Определенную роль сыграли его напористость и авантюрный характер. Пользуясь особым статусом Садовой конторы, он легко нарушал местные правила и предписания. Нельзя было набирать беглых крестьян на работу, а он часто это делал, так как рабочих рук постоянно не хватало. Казалось бы, его звание майора требовало от него подчинения и четкого выполнения указов, но в данном человеке авантюризм и стремление добиться результата во что бы то ни стало превалировалиㄴ․

Практически одновременно с Паробичем в Астрахань в 1735 г. по контракту приезжает итальянец Гиацинто Рисо. Согласно контракту: «он Рисо в Астрахани лоз размножать разными манерали и из винограда вино делать по эталонам франиузской манеры. Сады прививать и размножать в оранжереях разных иветов разводить». При приезде Рисо имел с собой ученика, несколько виноградных лоз (1 кадочка), саженцы грушевых деревьев (1 ящик) и различные семена для посадки (ГААО. Ф. 521. Ол. 1. Д. 1. л. 11-18). В период с 1753-1754 гг. при городских садах Г. Рисо удалось вырастить в оранжереях розы и разнообразные цветы, создать производство розовой воды для императорского двора и аптек, произвести разных сортов вино (вино сорта номер один и вино простого номера), развести «розмариновых деревьев» (ГААО. Ф. 521. Ол. 1. Д. 3. л. 49-100; л. 63-64).

Вообще Астраханские губернаторы и руководители садовой конторы на протяжении всего XVIII в. были заинтересованы именно в иностранных садовниках, которые имели опыт в выращивании разных сортов винограда и тутовых деревьев (ГААО. Ф. 394. Оп. 1 доп. Д. 199. л. 81).

1 В местной литературе его обычно называют венгром, что и понятно, ведь он прибыл из Австро-Венгрии. В 1732 г. Петр I обратился к сербам с призывом переселяться в Россию. Многие из переселенцев были из Vojna Krajina - «военной» границы между Австро-Венгрией и Оттоманской империей.

2 Именно это является косвенным предположением, что майор Паробич прибыл из Vojna Krajina - настоящей фронтирной территории, где не существовало уж таких жестких предписаний. Здесь трансгрессия (культурная, хозяйственная) оказывалась лучшим способом выживания. Жителям Крайины приходилось выживать в суровых условиях, вести хозяйство, но и быть готовыми отразить атаки врага. 
В 1764 г. из Петербурга в астраханскую садовую контору на три года был послан французский садовник Еган Бартман для работы в оранжереях и обучения садовников. По его указанию в астраханских садах были созданы парники и новые оранжереи, которые создавались учитывая особенности астраханского климата (ГААО. Ф. 521. Оп. 1. Д. 32. л. 43; л. 105).

Под руководством Паробича А. И. при садах создавались винокуренный и пивоваренный завод (ГААО. Ф. 394. Оп. 1 доп.. Д. 62. л. 53). Помимо этого, функционировал шелковый завод для нужд которого разводили тутовые деревья при казенных и частных садах для разведения шелковичного червя 1 .

Во второй половине XVIII в. в городских садах также выращивали тутовые и миндальные деревья, орехи, цитрусовые, специи, цветы и мн. др. (ГААО. Ф. 521. Оп. 1. Д. 32. л. 39).

Но не только в столицу отправляются так желанные овощи и фрукты. В Астрахани в огромном количестве производят стручковый перец и гвоздику, экспортируемые в Персию и Индию (Гасанов, 2017, с. 61; Магомедов \& Магарамов, 2014, с. 107)

В 1770 г. французский винодел Жозеф Банк, уроженец из города Марсейан Лангедокской провинции, предложил России свои услуги по внедрению французских технологий виноградарства и виноделия. 27 февраля 1779 г. Ж. Банк заключил контракт с астраханской Садовой конторой, согласно которому он обязывается: привести в хорошее состояние и умножать астраханские и красноярские сады; высадить миндальные, оливковые и тутовые деревья, привезенные из Италии; учредить винокуренный завод в Астрахани и наладить обширное производство французской водки на российском рынке. В России Ж. Банк являлся редким специалистом, о котором отзывались как об умелом мастере в разведении виноградных садов и в производстве хорошего вина согласно французскому методу (ГААО. Ф. 521. Ол. 1. Д. 231. л. 15-17). Из Петербурга Ж. Банк в Астрахань приехал со своей семьей, получив жилье и жалование в размере 1000 рублей. В Астрахани Ж. Банку удалось произвести белое и красное вино по новому образцу высадить в 1780 г. две тысячи кустов виноградной лоз, собрать большой урожай яблок, абрикосов, чернослива, тутовника, вишни, грушевых, в том числе и скрещенных сортов, привезенных из Италии (ГААО. Ф. 521. Оп. 1. Д. 259. л. 1; л. 80-81). В 1782 г. винодел предложил князю Потемкину Г. А. свой проект развития виноделия в Петербурге, но в этот период императрица Екатерина II предлагала развивать виноделие на Юге России - в Астрахани и Крыму. В 1783 г. по указанию князя Потемкина Г. А. для разведения виноградных садов Ж. Банк был направлен на полуостров Крым, на котором ему удалось в период 1783-1785 гг. собрать крупный урожай с крымских поместий императорской семьи, из которого было получено 240 гектолитров вина (Олливье, 2008, с. 46-63).

1 Фабрика по разведению шелковичного червя для получения шелка функционировала в Астрахани до 60-х гг. ХХ в. 
Но не только виноград и специи были особой изюминкой края. Могли астраханцы похвастаться и тропической экзотикой. По инициативе Паробича А. И. в астраханских садах предприняли попытку вырастить тропическое растение - ананас. Количество высаженных ананасов в 1764 г. составило 250 кустов (ГААО. Ф. 521. Оп. 1. Д. 32. л. 39). На императорский двор доставляли по 2 ананаса каждый год в период 1763-1764 гг. (ГААО. Ф. 521. Оп. 1. Д. 26. л. 169). В 1775 г. на императорский стол в начале и в конце августа доставлялось уже от 6 до 7 ананасов, а также различных сортов дынь, айвы, арбузов и винограда (ГААО. Ф. 521. Оп. 3. Д. 21. л. 2).

Ну и хотелось бы отметить еще один важный момент, помогающий нам обозначать Астраханскую садовую контору через призму имперскости. Ведь особом свойством подобных институтов является то, что они воспроизводят себя, репродуцируя имперское пространство и продуцируя специалистов, призванных этот институт обслуживать. Уже в 1758 г. по инициативе тайного советника Адама Васильевича Олсуфьева при Садовой конторе была учреждена школа «для обучения малолетних детей российской грамоте, арифметике, геометрии при астраханских садах» (ГААО. Ф. 521. Оп. 1. Д. 1. л. 295).

\section{От заката до рассвета. Сложные судьбы имперского сада}

Развитие института имперского сада в России является достаточно сложным и противоречивым. С одной стороны, быстрый и эффектный старт показывает, насколько этот процесс соответствовал мировому уровню развития этого института, а в некоторых вопросах и опережал его. Но одновременно, он развивался волнообразно, и после подъема наступил спад. Причины этого были самые разнообразные, но чаще всего преимущественно субъективные. На примере астраханских садов это очень хорошо заметно. К 1780-м гг. астраханские городские сады приходят в упадок. На момент 1786 г. в ведомстве садовой конторы имелось 20 виноградных садов и 2 сада для выращивания различных деревьев. На один виноградный сад приходились 1-2 ветряных мельницы, а количество виноградной лозы варьировалось от 2,5 тыс. до 6 тыс. кустов на один сад. В некоторых садах еще оставались оранжереи (ГААО. Ф. 521. Оп. 1. Д. 293. л. 17-19).

И, как ни странно, основной причиной этого упадка является именно имперская политика. Продвижение границ России дальше на юг меняло карту, да и природный и культурный ландшафт страны. Освоение новых территорий требовало все больше ресурсов: экономических, политических, человеческих и т.Д..

Одна из основных причин упадка астраханских садов заключалась в недостаточном количестве квалифицированных садовников, переезжающих в присоединенные к России земли (ГААО. Ф. 394. Оп. 1. Д. 5101. л. 1-20). Второй причиной являлась сильная засуха, при условии, что в жаркое лето и осень 
глинисто-песчаный грунт требовал обильного полива, без которого виноград становиться сухим и непригодным для выделки хорошего вина, а именно этот продукт и являлся, по мнению центра, базовым для поддержания работы этого учреждения. В итоге в 1787 г. Садовая виноградная контора была реорганизована, а казенные сады были переданы в ведомство Городского магистрата и Шестигласной думы Астрахани (ГААО. Ф. 521. Оn. 1. Д. 293. л. 1-6). Конечно, это не означало полнейшей гибели этого института в крае. К этому моменту Астрахань уже завоевала определенный статус города-сада, поэтому занятие садоводством и огородничеством все еще остается прибыльным делом в губернии. Но отношение Центра к ней как особой перспективной территории полностью утрачено. В Приоритетах Крым и другие территории.

В тоже время развитость садоводства как перспективной отрасли продолжает давать свои плоды, хоть и не столь эффективно, как раньше. Все еще делаются попытки интродуцировать новые растения. Так в начале XIX в. в городских садах пытались вырастить кунжут с целью получения кунжутного масла. Кунжут был привезен из Санкт-Петербурга. И даже в этом аспекте вновь имперская политика проявила себя в полной мере: в астраханской полиции предполагали ${ }^{1}$, что в качестве специалистов можно будет использовать пленников из Бухары и Хивы, имеющих опыт в разведении кунжута и производстве масла. Кунжут удалось вырастить, но широкого производства так и не смогли организовать из-за климатических условий (ГААО. Ф. 1. Оп. 3. Д. 686. л. 1-8). Хотя возможно, что просто не было специалистов, знающих специфику выращивания новых культур. Об этом свидетельствует следующий казус. В 1819 г. одному местному умельцу удалось вырастить шафран, который он посадил в саду тутовых деревьев. Этим случаем активно заинтересовались местные чиновники, начавшие проверку чтобы выяснить, за счет какого финансирования простому татарину удалось вырастить новую культуру. Инспектор по шелководству провел исследование чтобы узнать какие в итоге результаты были получены в ходе выращивания нового растения. Согласно мнению инспектора, для выращивания любой культуры в городских садах требовались конкретные основания (ГААО. Ф. 1. Оп. 6 m. 1. Д. 146. л. 1-2). Как видно из материалов дела, астраханские власти были в большей степени взволнованы самовольными действиями крестьянина, чем обрадованы положительным результатом его эксперимента.

Когда анализируешь развитие имперского сада во второй половине XVIII в., невольно обращаешь внимание на тот факт, что все эти взлеты и падения происходили в период правления Екатерины II. И здесь концепт имперскости заметен особо ярко. Говоря про имперскую политику императрицы, шведский историк культуры Андреас Шёнле обращает наше внимание

1 Когда за дело садов берется полиция, легко предугадать результат этого «руководства». Почему именно Российская полиция была связана с садами, мы поговорим чуть позднее. Но на наш взгляд, если судить по истории даже столичных садов, становится понятной вся ущербность такого подхода. 
на один фрагмент из переписки Г. Потемкина и Екатерины, свидетельствующий, по нашему мнению, всю важность имперского императива (Schönle, 2001, pp. 1-2). Агитируя в 1782 г. Екатерину за взятие Крыма, Потемкин заявляет:

Всемилостивейшая Государыня! Неограниченное мое усердие к Вам заставляет меня говорить: презирайте зависть, которая Вам препятствовать не в Силах. Вы обязаны возвысить славу России. Посмотрите, кому оспорили, кто что приобрел: Франция взяла Корсику, Цесарцы без войны у турков в Молдавии взяли больше, нежели мы. Нет державы в Европе, чтобы не поделили между собой Азии, Африки, Америки. Приобретение Крыма ни усилить, ни обогатить Вас не может, а только покой доставит... < > Если твоя держава - кротость, то нужен в России рай. Таврический Херсон! (Лопатин, 1997, с. 155).

И хотя письмо написано за несколько месяцев до присоединения Крыма, но он уже мыслиться Потемкиным как будущий рай.

И здесь мы вновь возвращаемся к концепции рая. Именно рай оказывается универсальным тропом, вокруг которого и наращивается империя. Сложно удержаться, чтобы не сказать: все тропы ведут в рай. Как правило, чаще всего он мыслился в метафорах тропической идиллии. Конечно, в случае с Россией имеются определенные особенности. У нее отсутствовали «заморские» территории, где бы она могла этот рай провозгласить. Но это не значит, что сама идея не была актуальной в России. На роль рая или райского сада постоянно примерялись различные территории. В XVIII в. на нее претендовала Астраханская губерния. Здесь росли сочные фрукты, виноград, стараниями многих талантливых агрономов и ботаников в этот период в Астрахани выращивали различные специи, губернатор Бекетов даже предпринимал в 1778-79 гг. попытки начать в Астрахани выращивать сахарный тростник ${ }^{1}$, но опыт этот оказался неудачным (Штукенберг, 1858, p. 20). Однако, Екатерина II не оставляла надежду основать в Астрахани сахарный завод, который бы работал на сырье привозимым из Южного Азербайджана (Лопатин, 1997, с.146).

Астрахань по всем параметрам напоминала какое-то особое место тропического изобилия: спаржа и каперсы, растущие в диком состоянии вокруг города, хорошие урожаи кунжута ${ }^{2}$, различные красильные растения (марена, сода и многие другие), ананасы. Мы говорили уже и про обилие различных фруктов и овощей ${ }^{3}$.

Как нам кажется, этот статус региона изобилия неслучайно был определен для Астрахани. Крым, который мог бы претендовать на роль «рая»

1 В проекте учитывалось, что в Астрахани холодные зимы, поэтому предприняли попытку посадить его в озеро, чтобы он мог прозимовать подо льдом, но зима оказалась настоль холодной, что озеро промерзло до дна. В XIX в. на территории России тростник выращивали в Юго-Восточном Азербайджане - в Талышском ханстве.

2 В 1831 г. было собрано около 2 т. кунжута, но на следующий год все плантации кунжута померзли (Штукенберг, 1858, с. 21)

3 И в советский период Астрахань выполняла роль «всесоюзного огорода», поставляя стране в огромном количестве томаты, кабачки, баклажаны, арбузы, дыни и многие другие плоды. 
присоединили лишь в конце XVIII в., и позднее он очень активно начал перетягивать на себя эту роль, в то время как Астрахань все больше ее теряла'.

Конец XVIII в. стал переломным моментом в развитии имперской составляющей сада. Начало XIX в. ознаменовалось поиском новых форм. Очень хорошо это заметно на примере Санкт-Петербурга, где наглядно проявилось своеобразие формирования концепта «сада» как особого имперского инструмента. Как и в Астрахани, этот процесс шел волнообразно, и в нем то усиливались, то ослабевали тенденции имперскости. Общепринято считать, что Ботанический сад в Санкт-Петербурге берет свое начало с Аптекарского огорода, основанного Петром I в 1713 г. $^{2}$. Но достаточно быстро перерос свое «аптекарское» или точнее медицинское предназначение, превращаясь постепенно в имперский институт. Началом этого процесса, видимо, следует считать конец 20-х гг. XVIII в., когда в С.-Петербург из длительной экспедиции в Сибирь вернулся немецкий ботаник Д. Мессершмидт, привезший с собой огромное количество образцов сибирской флоры. В дальнейшем пополнение этой коллекции растительных образцов из удалённых уголков империи продолжили приехавшие из Германии ботаники Иоганн Сигизбек и Иоганн Амман, основавшие ещё один Аптекарский огород на Васильевском острове в 1735 г..

Говоря об аптекарском огороде как об особом институте, следует понимать, что его роль не может быть сведена только к имперским практикам, так как он представлял собой очень сложное полифоническое явление, в котором переплетались самые разнообразные тенденции и практики. Противоречивость этих ботанических практик, рассматриваемых нами во взаимосвязи с концепцией империи, требует постоянно различных уточнений и комментарий. Легко заметить, что во многом, особенно на первоначальном этапе, деятельность огорода (сада) в значительной степени направлялась усилиями немецких и других европейских ученых, приглашенных в Россию. В тоже время российские власти не всегда в полной мере понимали значимость всех усилий по созданию и функционированию этого и других подобных институтов ${ }^{3}$. Типичном примером подобного, несколько пренебрежительного

1 Это соперничество Астрахани с другими южными территориями России за статус «страны изобилия» представляется нам достаточно интересной проблемой, позволяющей нам увидеть ряд сложным политических процессов, происходящих в стране. Интересно и нынешнее состояние этого соперничества, примечательна и утрата этого статуса Астраханью в конце XX в.. Выдвинутый краснодарскими пиарщиками лозунг «Если есть на свете рай - это Краснодарский край» наглядно показывает, что на символическом уровне концепт рая не утратил свое значение, а общенациональный статус «рая» или «страны изобилия» сместился с территории Астрахани намного южнее. И этому есть ряд объективных и субъективных причин.

2 На самом деле это был не первый Аптекарский огород. Подобные «огороды»- учреждения для выращивания лекарственных растений - существовали в Москве и в XVII в., а возможно и раньше (Цицилин, 2021).

3 Впрочем, следует отметить, что в начале XX в. историки ботанического сада очень хорошо понимали этот аспект. Во многом деятельность Петра I в этом вопросе была новаторской и осуществлялась только на его энтузиазме и с помощью иностранных ботаников: «Очень часто не учитывается то обстоятельство, 
отношения к этому может служить судьба уже упомянутого Д. Мессершмидта, так и не сумевшего в полной мере реализовать себя в России, и умершего в бедности. Привезенные из Сибири свои дневники и наблюдения он так и не смог издать, хотя они содержали уникальный материал и получили великолепные отзывы известных натуралистов и путешественников (Новлянская, 1970, сс. 163-166). В то же время зарубежные ученые, работавшие на Россию, вели активную переписку с зарубежными ботаническими садами, обменивались необходимыми материалами и литературой с зарубежными коллегами ${ }^{1}$, и во многом привносили в свою деятельность правила и традиции садоводства, сложившиеся за пределами России. Это все означает, что часто форма имперского сада в России не всегда соответствовала его идеологическому содержанию, так как не всегда присутствовало понимание истинного значения этого института.

Следующий момент, который хотелось бы уточнить, касается опять же концепта подобного сада. Длительное использование термина «огород» показывает, что в сознании российских властей еще не произошло разделение понятий "hortus" и "horti". Во многом эти учреждения были призваны скорее обслуживать медицину, чем аккумулировать биологические ресурсы, как в других странах. Смена названия в 1735 г. с «аптекарского огорода» на «медицинский огород» подтверждает этот тезис. Хоть многие действия Петра I в этом вопросе мы классифицируем как имперские, однако, во многом он представлял их максимально практически, воспринимая все это в рамках медицинской ботаники ${ }^{2}$. Эта традиция продолжалась долгое время и после его смерти.

И даже Екатерина II, много сделавшая для развития паркового искусства, не в полной мере понимала значение Сада для империи. И хотя в 1798 г. Медицинский сад получил статус Ботанического сада, это мало могло изменить в его существовании, так как он все еще принадлежал Министерству внутренних дел ${ }^{3}$.

тот психологический момент, что понимать Петра В. было некому, не потому, что не было русских людей, способных понимать Петра, а потому, что таково было положение Петра В. Единственным удобным элементом, способным проводить его идеи, были иностранцы, которым не приходилось считаться со всем тем, что сложилось веками на Руси, и что нарушать всякому русскому было трудно. Со своими сотрудниками-иностранцами Пётр В. и совершал великия преобразования, с ними же он и насадил науки в России. С одним из этих иностранцев, именно с шотландцем Эрскином, он основал Аптекарский огород» (Фишер-фон-Вальдгейм, 1913, с. 60). Но, как нам кажется, эти замечания были верны лишь отчасти. Аптекарские огороды существовали на Руси и до этого, была практика сбора лекарственных трав и траволечения. Уже изначально, Петр I выстраивал свое детище в совершенно новом ключе. Он был первым, кто формировал именно имперский сад, пусть и назвался он «огород»

1 Так, например, Иоганн Амман был членом Лондонского королевского общества.

2 Следует, однако, понимать, что в начале XVIII в. власти искали новые подходы к управлению всеми этими институтами. Так изначально аптекарские огороды находились в ведении Посольского приказа.

3 Здесь уместно вспомнить то, как полицейские в Астрахани пытались решить проблему с выращиванием кунжута. 
В целом можно все-таки констатировать, что на рубеже веков происходила постепенно смена культурной и идеологической парадигмы имперского сада. И даже если Ботанический сад в Санкт-Петербурге и был не в очень хорошем состоянии, но параллельно развивались частные сады, которые могли бы в полной мере посоревноваться с казенными садами. Подобными садами были сады графа А. Разумовского (Соколов, 2020, сс. 194-195), сады Демидовых (Багоцкий, 2015; Чернов, 2010, 2011), А. Турчанинова (Пирогова, 2019) ${ }^{1}$ и многие другие.

Конец XVIII - нач. XIX вв. являются переломными в развитии института имперского сада. Пребывание Петербургского ботанического сада в ведении Министерства внутренних дел отрицательно сказалось на развитии этого института:

1806-1809 гг. сад потерял часть своей территории, так как профессор Стефан, бывший директором Ботанического сада, отдал ее под огороды в ведомство Полицейского департамента МВД (Потёмин, 2018, с. 731).

K 20-м годам XIX в. состояние Петербургского ботанического сада оказалось в ужасном состоянии. В докладе управляющего Министерством Внутренних дел ${ }^{2}$ Александру I о состоянии Ботанического сада, входящего в состав Императорской Медико-хирургической Академии, сообщалось:

По обращении Академии сей в 1822 году в Управление Министерства Внутренних дел, я не оставил обратить внимание на заведение сие и нашел оное в самом невыгодном положении и несоответствующим ни пользе, которой от онаго ожидать должно для учащихся, ни приличию; ибо Ботанический сад сей и теплицы онаго более были похожи на какое-либо маленькое заведете частнаго человека, нежели на учреждение такого Правительства, которое никогда ни чего не щадило для учебных и других общественных заведений (ПСЗРИ-І, Т 38 c. 858).

Нет никакого сомнения, что граф Кочубей, дипломат и опытный общественный деятель, очень хорошо осознавал значимость подобного учреждения, тем более у него самого имелся сад с оранжереей в его родовом поме-

1 Особо примечательны, на наш взгляд, ботанические сады промышленников Г. Демидова и А. Турчанинова в Солекамске, где им удалось создать в, казалось бы, неблагоприятных климатических условиях уникальные ботанические сады, содержащие самые разнообразные растения. И Демидовы, и Турчанинов вели активную переписку со знаменитыми натуралистами Европы, обменивались гербариями и посадочным материалом, активно поддерживали исследовательские экспедиции. Помимо Григория Демидова, ботанические сады были и у его братьев - Прокофия и Никиты. Уникальность ботанического кейса Демидовых и Турчанинова заключается в том, что они был не аристократами, а представляли новое сословие - промышленников. Они очень хорошо ощущали своеобразие этой эпохи, нашедшее свое выражение не только в духе предпринимательства, но и развитии науки, образовании и т.д.. В этой картине мира ботанический сад, являвшийся символическим воплощением рая, занимал важное место. Примечателен тот факт, что на одной из картин Порфирий Демидов даже изображен опирающимся на садовую лейку, а правая рука показывает на горшки с цветами - уникальный сюжет для парадного портрета XVIII в.

2 Министром Внутренних дел в этот период был граф В.П. Кочубей, который получил назначение на эту должность в ноябре 1819 г. 
стье. Начало века нам демонстрирует активизацию интереса к Саду, как особому учреждению, призванному подтвердить величие империи. Поэтому неудивительно, что очень много ботанических садов возникает на периферии государства: в 1803 г. в г. Тарту, в 1804 г. в Харькове, в 1807 г. в Кременце, в 18012 г. в Ялте, в 1819 г. в Одессе. Этот список можно было бы продолжить, но ясно, что большинство созданных ботанических садов убедительно свидетельствуют, что наступил новый этап, в котором сад оказывается теперь сугубо научным или образовательным учреждением, так как во многом связан с создаваемыми в этих местах университетами. Нет нужды пояснять, что университет является мощным инструментом продвижения государственной идеологии ${ }^{1}$.

Доклад графа Кочубея очень хорошо демонстрирует то, как к Ботаническому саду относились в последней трети XVIII в., и как начали воспринимать этот институт в начале нового века².

Как ни странно, но и в этом процессе отразилось все многообразие имперских практик в этот период. Во многом ботанический сад оказывается инструментом утверждения своего величия, богатства. Это очень хорошо заметно по деятельности Демидовых, Турчанинова и других. Создавая ботанический сад в Соликамске, его обладатель демонстрировал не только свое богатство, но и свою просвещенность и прогрессивность. Помимо ботанических увлечений практически у всех них были и уникальные коллекции минералов, каких-то раритетных предметов, книг и т.д. (Пирогова, 2019).

Еще раз обратим внимание, на то, что в первых двух десятилетиях образуются ботанические сады (и университеты) на периферийных территориях, где они и выступают в качестве имперских инструментов. Они снабжаются сырьем из центра, но и сами призваны поставлять в центр раритетные экземпляры.

Изменение фронтирного статуса региона коренным образом повлияло и на общую ситуацию. Те регионы (как Астрахань), которые еще недавно были флагманами имперского садоводства теперь обречены на угасание. И если экономическое значение регионов и не снизилось, то идеологическое ими было утрачено, что в конечном итоге и привело к определенной деградации.

1 Для сравнения приведем слова российского историка члена-корреспондента С.-Петербургской Академии наук профессора В. И. Герье, изучавшего влияние Г. Лебница на Петра и вообще на развитие России: «Школы Лейбниц советовал устроить, если возможно, при монастырях, университеты же в главных городах, как Москва, Киев, Астрахань, и т. д. Замечательно, что Лейбниц перечисляя города, в которых следовало учредить университеты, всегда называет Астрахань. Нам кажется, что выбор Астрахани для университета в восточной полосе России удачнее, чем в последствии действительно состоявшийся выбор Казани. Влияние Казани на сибирский край и поддержка, извлекаемая оттуда Казанским университетом, очень незначительны, тогда как университет в Астрахани достиг бы гораздо скорее высокаго процветания, ибо притягивал бы к себе умственные силы не только приволжскаго, но и всего кавказского края и сделался бы истинным рассадником русскаго просвещения на востоке» (Герье, 1871, сс. 192-193). В этих словах Герье как нельзя лучше отразил всю суть университета и университетского образования как инструментов имперского влияния.

2 Присвоение Ботаническому саду в 1823 г. статус Императорского коренным образом изменило и ситуацию с ним. Он получили достаточное финансирование и внимание со стороны власти. 
Астраханский кейс хорошо демонстрирует то, как садоводство все больше теряет свою значимость для региона. Так и не произошло накопление знаний, новых специалистов в регионе не появилось, ассортимент выращиваемых растений даже снизился. Астрахань в XIX в. в отличие от ситуации XVIII в. уже больше не была имперским городом. Она постепенно превращалась в провинцию, хотя экономически и продолжала развиваться. Лишь часть отраслей промышленности продолжали сохранять имперский характер, особенно это ярко проявилось во второй половине XIX в..

\section{Заключение}

Конечно, данная статья не претендует на исчерпывающее исследование обозначенной проблемы, так как феномен имперского сада остается еще мало изученной и сложной проблемой. Мы лишь коснулись некоторых вопросов, попытавшись обрисовать картину в целом. Часть проблем имперского сада так и остались за пределами нашего исследования. Мы не разобрали тенденции в построении пространства имперского сада, а это также очень важный механизм утверждения идеи империи. Было бы интересно рассмотреть то, как функционировал институт имперского сада вне наличия собственно «сада», реализуясь лишь как метафора. Интересно и то, как эти имперские практики продолжили свое существование в советскую эпоху, приняв особую форму насаждения монокультур в ряде регионов. И как эта монокультурность влияла на сельскохозяйственный ассортимент региона. Астраханская область демонстрирует этот процесс очень наглядно. Здесь произошло вытеснение и полное забвение ряда уникальных сортов яблок, груш, винограда и некоторых других сельскохозяйственных продуктов в угоду занятиям овощеводством (томаты, бахчевые, кабачки и т.д.) $)^{1}$

Вместе с тем, мы можем констатировать, что сад оказывается одним из важнейших инструментов имперского строительства. Многие империи различных стран мира и в разные эпохи продуцируют один и тот же концепт сада, выступающий метафорой центра мира. Он располагается в столице и символизирует все богатство государства. И не важно, сад ли это растений или из золота. Важен сам факт изобилия, ну или точнее демонстрация этого изобилия, пусть и в символичной форме. В эпоху античности это еще и напоминание о победах и достижениях, а также собрание раритетов, доставленных в столицу и призванных свидетельствовать о величии государства и разнообразии всего, находящегося на его территории. Сад в эту эпоху и последующую - это еще и символ рая, парадиза - идеального места изобилия и гармонии.

Имперский сад в Новое время - это особое явление, совмещающее в себе традиции античности и прагматичность Нового времени, направленную на получение ценных ресурсов. Не стоит забывать и то, что собственно эпоха

1 Монокультуры отрицательно сказались и на многих экологических сторонах региона. 
Нового времени начинается с Великих географических открытий и поиска пути к получению восточных специй.

Начавшиеся колониальные захваты создают новую концепцию имперского сада. Он теперь одновременно находится в центре и на периферии. В некоторой степени имперский сад - это растение с развитой структурой. Периферия снабжает центр, но и центр обеспечивает периферию всем необходимым. Примечательно, что периферия в большой степени нацелена на получение практического результата, то центр - на академическую составляющую. Ботаника в этом аспекте оказывается концентрированным выражением имперскости, так как нацелена на процветание государства.

Развитие имперского сада в России в полной мере совпало с провозглашением и строительством империи. Однако, становление этого института в России шло очень сложно, и не всегда форма и содержание имперского сада соответствовали друг другу. С одной стороны, в самом начале российский имперский сад находился в фарватере мировых тенденций имперского садоводства, но форма, как правило, бала в значительной мере архаичной. Сад во многом существовал за счет знаний, привнесенных извне, и энтузиазма различных участников этого процесса - профессионалов и любителей. Наличие иностранных специалистов обеспечивало России активную связь с зарубежными ботаническими садами. Это давало возможность получать информацию о новых тенденциях в ботанике и делиться своими открытиями.

Своеобразной особенностью этого процесса в России было активное участие в становлении имперского сада российских промышленников из глубинки ${ }^{1}$ Такие промышленники как Демидовы, А. Турчанинов и другие не только были любителями садового искусства, но выступали в качестве профессиональных натуралистов и даже поддерживали активную переписку с К. Линнеем. Качество и богатство их коллекций могло бы поспорить с коллекциями ведущих зарубежных университетов и академий.

В этом процессе активно участвовали и петербургские и московские вельможи. Уникальные сады были у графа А. Разумовского, и у поборника самодержавия графа С. Уварова, и у упомянутого выше графа Кочубея и многих других.

Вместе с тем, следует констатировать, что развитие ботанических институтов в России в последней трети XVIII в. находится в глубоком кризисе. Это можно судить по С.-Петербургскому ботаническому саду, который в формальном плане так и остался на уровне «аптекарского огорода» (медицинского сада), предназначенного лишь для выращивания лекарственных растений $^{2}$ (Траянский, 1905, сс. 5-6). Получение Ботаническим садом статуса

1 Эта особенность в становлении института имперского сада разительным образом отличается от становления подобного же института в Великобритании или во Франции, где активную роль в этом вопросе играли военные и чиновники Ост-Индских компаний.

2 Функция важная, особенно в условиях распространения различных болезней и ведения длительных войн, но в целом эту функцию можно считать достаточно архаичной и не соответствующей широкому кругу имперских задач. То, что Медицинский сад был частью Медицинской коллегии, не способствовало 
Императорского кардинальным образом изменило ситуацию с ним, он получил необходимое финансирование, расширил штат научных работников и приобрел дополнительные площади.

Астраханский кейс имперских ботанических практик демонстрирует нам уникальное совпадение с общероссийскими тенденциями, а также показывает зависимость института имперского сада от фронтирного статуса региона. Пока Астрахань воспринимается как фронтирный регион здесь заметно активное развитие садоводства, интродуцируются многие растения, климатически несоответствующие региону, однако успешно выращиваемые и плодоносящие цитрусовые, ананасы, шафран, перец, кунжут. Предпринимаются попытки акклиматизации сахарного тростника, довольно успешно развивается виноградарство и виноделие. Во многом все это стало возможным благодаря действиям иностранных специалистов, направленных сюда для развития этой отрасли. Перевод некоторых из этих специалистов в Крым привел к упадку этой отрасли, отказу от многих субтропических и тропических культур и даже потере достигнутого в деле виноградарства и виноделия. В XIX в. хотя астраханцы активно и занимаются садоводством, однако, эта деятельность носить традиционный характер и направлена на внутренне потребление. Все усилия новаторов XVIII в. сведены на нет.

Вместе с тем, начало XIX в. ознаменовалось серьезными изменениями в этом вопросе. Во многих городах страны, расположенных во фронтирной зоне, возникают ботанические сады, имеющие статус научных и образовательных учреждений. Это показывает, что государство в большей мере начало осознавать важность функционирования этого имперского института, вы веденного на новый уровень. Все это можно отнести к определенным успехам Российской империи в ее закреплении на своих границах. Вполне понятно, что все эти вновь образованные сады не могли существовать без поддержки из центра, что создавало дополнительные связи центра и периферии. Если на первых этапах именно центр получал больше от периферии, то теперь провинциальные сады во многом зависели от Петербурга и в плане научной поддержки, и получения оттуда необходимых ресурсов (финансовых и природных).

Как нам кажется, все основные практики сформировались к середине XIX в., и во многом они продолжались даже в советский период. В них продолжилось доминирование вертикальных связей (центр-периферия), с меньшим участием горизонтальных.

раскрытию научного и общекультурного потенциала этого учреждения. 


\section{Список литературы}

Adelaar, W. F. H., \& Muysken, P. (2004). The languages of the Andes. Cambridge University Press.

Armstrong, J. A. (1982). Nations before nationalism. University of North Carolina Press.

Baber, Z. (2016). The Plants of Empire: Botanic Gardens, Colonial Power and Botanical Knowledge. Journal of Contemporary Asia, 46(4), 659-679. https://doi.org/10.1080/00472336.2016.1185796

Balabanlilar, L. (2012). Imperial identity in the Mughal Empire: Memory and dynastic politics in early modern South and Central Asia. I.B. Tauris; distributed in the United States and Canada exclusively by Palgrave Macmillan.

Barnard, T. P. (2018). Nature's Colony: Empire, Nation and Environment in the Singapore Botanic Gardens (NUS Press).

Brockway, L. H. (2002). Science and colonial expansion: The role of the British Royal Botanic Gardens. Yale University Press.

Chatterjee, D. (1948). Early History of the Royal Botanic Garden, Calcutta. Nature, 161(4088), 362-364. https://doi.org/10.1038/161362a0

Cobo, F. B. (1979). History of the Inca Empire. University of Texas Press.

Daryaee, T. (2013). Sasanian Persia: The rise and fall of an empire (New paperback edition). I.B. Tauris \& Co. Ltd in association with the Iran Heritage Foundation.

Dearborn, D. S. P., Seddon, M. T., \& Bauer, B. S. (1998). The Sanctuary of Titicaca: Where the Sun Returns to Earth. Latin American Antiquity, 9(3), 240-258. https://doi.org/10.2307/971730

Doyle, M. W. (1986). Empires. Cornell University Press.

Gerasimov, I., Kusber, J., \& Semyonov, A. (2009). Empire speaks out: Languages of rationalization and self-description in the Russian Empire. Brill. http://site.ebrary.com/id/10439122

Gharipour, M. (Ed.). (2017). Gardens of Renaissance Europe and the Islamic empires: Encounters and confluences. The Pennsylvania State University Press.

Hartswick, K. J. (2004). The gardens of Sallust: A changing landscape (1st ed). University of Texas Press.

Kipling, R. (1897). The writings in prose and verse of Rudyard Kipling (C. Scribner's sons).

Kolata, A. L., \& de Diez Canseco, M. R. (2000). History of the Inca Realm. The American Historical Review, 105(2), 591. https://doi.org/10.2307/1571555

Luttikhuizen, G. P. (1999). Paradise Interpreted: Representations of Biblical Paradise in Judaism and Christianity (Brill). BRILL.

Matsuzato, K. (Ed.). (2010). Comparative imperiology. Slavic Research Center, Hokkaido University.

McCracken, D. P. (1997). Gardens of empire: Botanical institutions of the Victorian British empire. Leicester University Press.

McEwan, G. F. (2006). The Incas: New perspectives. ABC-CLIO.

Mintz, S. W. (1986). Sweetness and Power: The Place of Sugar in Modern History (Reprint edition). Penguin Books.

Moosvi, S. (1987). The economy of the Mughal Empire, c. 1595: A statistical study. Centre of Advanced Study in History, Aligarh Muslim University; Oxford University Press. 
Mukerji, C. (1997). Territorial ambitions and the gardens of Versailles. Cambridge University Press.

Newman, A. J. (2021). The Safavid Empire.

Nicosia, M. (2017). Milton's Banana: Paradise Lost and Colonial Botany. Milton Studies, 58(1), 49-66. https://doi.org/10.1353/mlt.2017.0003

Pagden, A. (1998). Lords of all the world: Ideologies of empire in Spain, Britain and France, 1492 - 1830. Yale University Press.

Pliny, the E. (1967). Natural history (Harvard University Press, Vol. 5).

Richards, J. F. (1993). The New Cambridge History of India, The Mughal Empire,: Vol. 1.5 (Cambridge University Press).

Romaniello, M. P. (2016). True rhubarb? Trading Eurasian botanical and medical knowledge in the eighteenth century. Journal of Global History, 11(1), 3-23. https://doi.org/10.1017/ S1740022815000327

Rostworowski de Diez Canseco, M. (1999). History of the Inca realm. Cambridge University Press.

Rostworowski de Diez Canseco, M. (2000). Estructuras andinas del poder: Ideologia religiosa y politica. IEP.

Ruggles, D. F. (1994). Vision and power at the Qala Bani Hammad in Islamic North Africa. The Journal of Garden History, 14(1), 28-41. https://doi.org/10.1080/01445170.1994.10412495

Sarmiento de Gamboa, P. (2007). The history of the Incas (1st ed). University of Texas Press.

Schönle, A. (2001). Garden of the Empire: Catherine's Appropriation of the Crimea. Slavic Review, 60(1), 1-23. https://doi.org/10.2307/2697641

Steele, P. R., \& Allen, C. J. (2004). Handbook of Inca mythology. ABC-CLIO.

Stoler, A. L. (2009). Considerations on Imperial Comparisons. In Empire speaks out: Languages of rationalization and self-description in the Russian Empire (Brill).

Streusand, D. E. (1989). The formation of the Mughal Empire. Oxford University Press.

Suny, R. G., \& Martin, T. (Eds.). (2001). A state of nations: Empire and nation-making in the age of Lenin and Stalin. Oxford University Press.

The Botanic Garden of Pamplemousses. (1919). Bulletin of Miscellaneous Information (Royal Gardens, Kew), 1919(6/7), 279. https://doi.org/10.2307/4111532

Thomas, A. P. (2006). The Establishment of Calcutta Botanic Garden: Plant Transfer, Science and the East India Company, 1786-1806. Journal of the Royal Asiatic Society of Great Britain \& Ireland, 16(2), 165-177. https://doi.org/10.1017/S1356186306005992

Waters, M. W. (2014). Ancient Persia: A concise history of the Achaemenid Empire, 550-330 BCE. Cambridge University Press.

Zuidema, T. R. (1964). The ceque system of Cuzco: The social organization of the capital of the Inca (E.J. Brill).

Zuidema, T. R. (1990). Inca Civilization in Cuzco (University of Texas Press).

Багоцкий, С. В. (2015). Г. А. Демидов: Русский миллионер и ботаник. Бюллетенъ Московского Общества Испытателей Природы. Отдел Биологический, 120(5), 85-87. 
Баллас, М. (1895). Виноделие в России. Историко-статистический очерк. Часть 1. (Типография В. Киршбаума).

Березкин, Ю. Е. (1991). Инки: Исторический опыт илперии. (Наука).

ГААО. Ф. 1. ОП. 3. Д. 686.

ГААО. Ф. 1. Оก. 6 m. 1. Д. 146.

ГААО. Ф. 13. ОП. 1. Д. 1879.

ГААО. Ф. 394. Оп. 1. Д. 5101.

ГААО. Ф. 394. Оп. 1 доп. Д. 62.

ГААО, Ф. 394. On. 1 доп. Д.199.

ГААО. Ф. 521. ОП. 1. Д. 1.

ГААО. Ф. 521. Оп. 1. Д. 3.

ГААО. Ф. 521. ОП. 1. Д. 26.

ГААО. Ф. 521. ОП. 1. Д. 32.

ГААО. Ф. 521. ОП. 1. Д. 231.

ГААО. Ф. 521. Оп. 1. Д. 259.

ГААО. Ф. 521. ОП. 1. Д. 293.

ГААО. Ф. 521.ОП. 3. Д. 21.

Гасанов, М. Р. (2017). К вопросу о связях Дагестана с Астраханью в XVII - первой трети XVIII в. Научная Мысль Кавказа, 2, 52-63.

Герасимов, И., Могильнер, М., \& Семенов, А. (2011). Изобретение илперии: Языки и практики. (Новое издательство).

Герье, В. И. (1871). Лейбнии и его век: Отношения Лейбнища к России и Петру Великому по неизданным бумагам Лейбница в Ганноверской библиотеке (Vol. 2). (Печатня В.И. Головина).

Инка Гарсиласо, де ла В. (1974). История государства инков (Наука).

Лопатин, В. С. (1997). Екатерина II и Г.А. Потемкин. Личная переписка 1769-1791 (Наука).

Магомедов, Н. А., \& Магарамов, Ш. А. (2014). Индийское купечество в развитии торговых контактов Дербента с Астраханью в XVII в. Грамота, 8-2, 105-108.

Новлянская, М. Г. (1970). Даниил Готлиб Мессершиидт (Наука).

Олеарий, А. (2003). Описание путешествия в Московию (Русич).

Олливье, Ж. (2008). Французский винодел в Екатерининской России (письма Ж. Банка князю Г.А. Потемкину). Россия и Франция XVIII-XX вв. Сборник статей. (Наука), 8, 46-63.

Пирогова, Е. П. (2019). Уральские заводчики и научные исследования XVIII в. Вестник СанктПетербургского Государственного Института Культуры, 3 (40), 92-97.

Полное собрание законов Российской Империи. Собрание Первое. 1649-1825 г2.: Tm. IV,VI (II Отделения Собственной Его Императорского Величества Канцелярии).

Поршнев, В. П. (2020). Императорские городские сады Древнего Рима. Вестник Санкт-Петербургского Государственного Института Культуры, 1(42), 69-75. 
Потёмин, М. А. (2018). Объект культурного наследия федерального значения «Ботанический сад». Отдельные исторические сведения по материалам паспорта объекта культурного наследия. Соблюдение требований законодательства в сфере охраны объектов культурного наследия. Hortus Botanicus, 13(1). https://doi.org/10.15393/j4.art.2018.5724

Рибер, А. (2004). Сравнивая континентальные империи. In Российская илперия в сравнительной перспективе (Новое издательство, сс. 33-70).

Советская историческая энциклопедия (1964) (Государственное научное издательство "Советская энциклопедия," Vol. 5).

Соколов, Б. М. (Ред.). (2020). Сады и парки в России: Опыт, проблемы, перспективы. Из истории Царицынского парка. Litres.

Сыма Цянь. (2003). Исторические записки (Ши цзи (Р. Вяткин, ред.; Восточнач литература, Т. 2).

Траянский, Е. В. (1905). Илператорский С.-Петербургский Ботанический Сад (Издательство П.П. Сойкина).

Фишер-фон-Вальдгейм, А. А. (1913). Илператорский С.-Петербургский Ботанический Сад за 200 лет его сущ,ествования (1713-1913). (Герольд, Т. 1).

Цицилин, А. Н. (2021). Ассортимент лекарственных растений в Аптекарских огородах Москвы в XVII веке. Биосфера, 1-2, 15-20.

Чернов, Н. Н. (2010). Ботанические увлечения уральских заводчиков Демидовых. Географический Вестник, 3, 77-79.

Чернов, Н. Н. (2011). Ботанические сады уральских заводчиков Демидовых. Леса России и Хозяйство в Них, 3 (40), 62-66.

Штукенберг, И. Ф. (1858). Статистическіе труды Ивана Федоровича Штукенберга (Т. 1).

Якушенков, С. Н., \& Палаткин, В. В. (2020). Мы наш и новый мир накормим: Несколько кейсов алиментарных традиций фронтирных регионов. Часть І. Журнал фронтирных исследований, 5(4), 237-258

Якушенков, С. Н., \& Якушенкова, О. С. (2021). Зомби как зеркало современной массовой культуры. Corpus Mundi, 2(4), 15-39. https://doi.org/10.46539/cmi.v2i4.52

\section{References}

Bagotsky, S. V. (2015). G. A. Demidov: Russian Millionaire and Botanist. Bulletin of the Moscow Society of Nature Explorers. Department of Biology, 120(5), 85-87. (In Russian)

Ballas, M. (1895). Winemaking in Russia. Historical and statistical sketch. Part 1. (Typography of V. Kirshbaum). (In Russian)

Berezkin, Y. E. (1991). The Incas: Historical Experience of the Empire. (Science). (In Russian)

Chernov, N. N. (2010). Botanical hobbies of the Ural plant breeders Demidovs. Geographic Bulletin, 3, 77-79. (In Russian)

Chernov, N. N. (2011). Botanical gardens of the Ural factory owners Demidovs. Forests of Russia and the Economy in Them, 3 (40), 62-66. (In Russian) 
Complete Collection of Laws of the Russian Empire. Sobranie Pervoye. 1649-1825: Vols. IV,VI (II Departments of His Imperial Majesty's Own Chancery). (In Russian)

Fisher-von-Waldheim, A. A. (1913). The Imperial S.-Petersburg Botanical Garden for 200 years of its existence (1713-1913). Vol. 1, (Herold). (In Russian)

GAAO, F. 394. Op. 1. Dop. D. 199.

GAAO. F. 1. Op. 3. D. 686.

GAAO. F. 1. Op. 6 т. 1. D. 146.

GAAO. F. 13. Op. 1. D. 1879.

GAAO. F. 521.Op. 3. D. 21.

GAAO. F. 394. Op. 1. D. 5101.

GAAO. F. 394. Op. 1. Dop. D. 62.

GAAO. F. 521. Op. 1. D. 1.

GAAO. F. 521. Op. 1. D. 231.

GAAO. F. 521. Op. 1. D. 259.

GAAO. F. 521. Op. 1. D. 26.

GAAO. F. 521. Op. 1. D. 293.

GAAO. F. 521. Op. 1. D. 3.

GAAO. F. 521. Op. 1. D. 32.

Gasanov, M. R. (2017). To the question about the relations of Dagestan with Astrakhan in the 17th - first third of the 18th century. Nauchnaya Mysl Kavkaza, 2, 52-63. (In Russian)

Gerasimov, I., Mogilner, M., \& Semenov, A. (2011). The Invention of Empire: Languages and Practices. (New Publishers). (In Russian)

Guerrier, W. I. (1871). Leibniz and His Age: Leibniz's Relations to Russia and Peter the Great by Leibniz's Unpublished Papers in the Hanoverian Library (Vol. 2). Printed by V.I. Golovin. (In Russian)

Inca Garcilaso, de la V. (1974). History of the Inca State (Nauka). (In Russian)

Lopatin, V. S. (1997). Catherine II and G. A. Potemkin. Personal correspondence 1769-1791 ( Nauka). (In Russian)

Magomedov, N. A., \& Magaramov, Sh. A. (2014). Indian merchants in the development of trade contacts between Derbent and Astrakhan in the 17th century. Gramota, 8-2, 105-108. (In Russian)

Novlyanskaya, M. G. (1970). Daniel Gottlieb Messerschmidt (Nauka). (In Russian)

Olearius, A. (2003). Description of the journey to Moskovia (Rusich). (In Russian)

Ollivier, J. (2008). The French Winemaker in Catherine the Great's Russia (Letters of J. Bank to Prince G.A. Potemkin). Russia and France in XVIII-XX centuries. A Collection of Articles, 8, 46-63. (In Russian)

Pirogova, E. P. (2019). Ural plant breeders and scientific research in the 18th century. Bulletin of the St. Petersburg State Institute of Culture, 3 (40), 92-97. (In Russian)

Porshnev, V. P. (2020). Imperial Urban Gardens of Ancient Rome. Vestnik St. Petersburg State Institute of Culture, 1 (42), 69-75. (In Russian) 
Potyomin, M. A. (2018). Object of cultural heritage of federal significance "Botanical Garden". Selected historical information on the materials of the passport of the object of cultural heritage. Compliance with legislative requirements in the sphere of protection of objects of cultural heritage. Hortus Botanicus, 13(1). https://doi.org/10.15393/j4.art.2018.5724 (In Russian)

Rieber, A. (2004). Comparing Continental Empires. In The Russian Empire in Comparative Perspective (New Publishing House, pp. 33-70). (In Russian)

Shtukenberg, I. F. (1858). Statistical Works of Ivan Fedorovich Shtukenberg (Vol. 1). (In Russian)

Sima Qian. (2003). Historical Notes (R. Vyatkin, ed.; Vostochnach literatury, Vol. 2). (In Russian)

Sokolov, B. M. (Ed.). (2020). Gardens and Parks in Russia: Experience, Problems, Prospects. From the history of Tsaritsynsky Park. Litres. (In Russian)

Soviet Historical Encyclopedia (1964) (State Scientific Publishing House "Soviet Encyclopedia," Vol. 5). (In Russian)

Trajansky, E. V. (1905). The Imperial S.-Petersburg Botanical Garden (P.P. Soikin Publishers). (In Russian)

Tsitsilin, A. N. (2021). Assortment of medicinal plants in the Apothecary Gardens of Moscow in the $17^{\text {th }}$ century. Biosphere, 1-2, 15-20. (In Russian)

Yakushenkov S. N. \& Palatkin V. V. (2020). We will Feed Our and a New World: Several Cases of Food Ways of Frontier Regions. Part I. Journal of Frontier Studies, 5(4), 237-258. (In Russian)

Yakushenkov S. N. \& Yakushenkova O. S. (2021). The Zombie as a Mirror of Modern Mass Culture. Corpus Mundi, 2(4), 15-39. https://doi.org/10.46539/cmj.v2i4.52 (In Russian) 